UCRL-53719

Distribution Category UC-70

UCRL--53719

DE87 000844

\title{
Radiation Chemical Effects in Experiments to Study the Reaction of Glass in an Environment of Gamma-Irradiated Air, Groundwater, and Tuff
}

R. A. Van Konynenburg

Manuscrip: date: May 2, 1986

\section{LAWRENCE LIVERMORE NATIONAL LABORATORY} University of California - Livermore, California 99455 
T.ABLE OF CONTENTS

Abstract............................................. 1

1. Introduction.......................................... 3

2. Description of Experiments and Results....................... 5

3. Discussion........................................... 15

3.1 Overview......................................... 15

3.2 Changes in Composition due to Heating................... 16

3.3 Overview of Major Features and Expected Observable Results...... 17

3.4 Gas Phase......................................... 19

3.5 I.iquid Phase...................................... 20

3.6 Gas and Liquid Phases Considered Together................... 29

3.7 Interactions with the solid Phase....................... 30

3.8 Decomposition of water $\ldots \ldots \ldots \ldots \ldots \ldots \ldots \ldots \ldots \ldots \ldots \ldots \ldots \ldots \ldots \ldots \ldots$

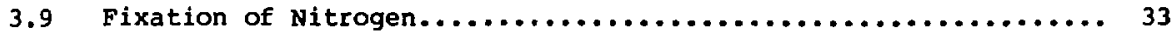

3.10 Hyarogen Ion Production.............................. 36

3.11 Nitrite-Nitrate Ratio............................... 36

3.12 Likely Effects on Glass Reaction....................... 40

3.13 High Gas-to-Liquid Volume Ratio Experiments............... 40

3.14 Anomalous Tests.................................. 42

4. Conclusions.......................................... 45

5. Application to the Repository......................... 47

References............................................ 51 


\section{RADIATION CHEMICAL EFFECTS IN EXPERIMENTS TO STUDY}

THE REACTION OF GLASS IN AN ENVIRONMENT OF

GAMMA-IRRADIATED AIR, GROUNDWATER, AND TUFF

\section{ABSTRACT}

The results of experiments performed by John $\mathrm{K}$. Bates et al. on the reaction of nuclear waste glass with a gamma-irradiated $90^{\circ} \mathrm{C}$ aqueous solution were analyzed using theory developed from past research in radiation chemistry. The aqueous solution they used is similar to what would be expected in a water-saturated environment in a nuclear waste repository in tuff. The purpose of our study was to develop an understanding of the radiation-chemical processes that occurred in the Bates et al. experiments so the results could be applied to the design and performance analysis of a proposed repository in unsaturated tuff in Nevada. For the Bates et al. experiments at the highest dose $(269 \mathrm{Mrad})$, which originally contained about $16 \mathrm{ml}$ of "equilibrated" water taken from Nevada Test Site Well J-13 and $5.4 \mathrm{ml}$ of air, we predicted that water decomposition to $\mathrm{H}_{2}$ and $\mathrm{O}_{2}$ would produce a pressure increase of at least $1.0 \mathrm{MPa}$ at $20^{\circ} \mathrm{C}$. We also predicted that nitrogen fixation from the air would occur, producing an increase of $1.6 \times 10^{-4} \mathrm{M}$ in total fixed nitrogen concentration in solution. In addition, an equimolar production of $\mathrm{H}^{+}$would occur, which would be buffered by the $\mathrm{HCO}_{3}^{-}$in the water. The fixed nitrogen in solution was predicted to be present as $\mathrm{NO}_{2}^{-}$and $\mathrm{NO}_{3}^{-}$with the ratio influenced by the presence of materials catalytic to the decomposition of $\mathrm{H}_{2} \mathrm{O}_{2}$. We found reasonable agreement between sur predictions and the observations of Bates et al., where comparisons were possible. We apply the results to the proposed Nevada repository to the degree possible, given the different expected conditions. 


\section{INTRODUCTION}

The Nevada Nuclear Waste Storagt Investigations (NNNSI) Project is evaluating the tuff deposits at Yucca Mountain in Nye County, Nevada, as a possible location for a high-level nuclear waste repository. Lawrence Livermore National Laboratory (LLNL) is responsible for waste package development for this site. An important aspect of this development is to predict the extent of release into the environment of radionuclides from the nuclear wate expected at the site. The waste form planned for the first defense high-level nuclear waste to be emplaced (as well as for the waste from the West valley, New York, facility) is borosilicate glass. Accordingly, we are study $i_{1} \exists$ the behavior of borosilicate glass under conditions similar to those in thi expected tuff repository environment.

We anticipate that the repository will be located in the unsaturated zone above the $w:-2$ table. We also expect that during the first 300 to 1000 years the waste form i ill be protected by sealed outer containers, and that the thermal power den ity from nuclear decay will be sufficient to prevent liquid water from coming 1 ito contact with most of the packages during this period. The maximum gamma dos? rate near waste packages containing the glass waste form is expected to be voout $5.5 \times 10^{3} \mathrm{rem} / \mathrm{hour}$ at the time of emplacement. 1 The dominant gamna emitte during the containment period will be ${ }^{137} \mathrm{Cs}$, with a half-life of 30.17 years. The gamma dose rate would thus decay by about 10 half-lives during a 300-year piriod, which is equivalent to about three orders of magnitude. The resulting dose rate would be a few rem/hour maximum after 300 years. Nevertheless, there is a small probability that some liquid water could contact some of the glass during the time when a significant gamma radiation dose rate was still present.

Past studies have shown that gamma irradiation can increase the rate and extent of reactions of nuclear waste glasses with deionized water and aqueous solutions compared to what is observed in the absence of radiation; Pederson and MCVay provide a recent review of these studies. ${ }^{2}$ The largest increases have been seen when air was in contact with the solution, because of the production of nitric acid during irradiation and the resulting lowering of the pH. 3-6 Smaller increases have been attributed to the transienu radical species produced by irradiation of the water, particularly the hydroxyl radical OH. 7 
We expect that a repository located in tuff at Yucca Mountain would be open to gaseous exchange with the atmosphere because of the fractures and connected porosity of the rock. Therefore the potential for nitric acid production would exist. The presence of dissolved $\mathrm{CO}_{2}$ also raises the possibility of production of carboxylic acids, which can act as chelating agents increasing corrosion and dissolution rates.8-12 However, the expected water composition includes bicarbonate as the major anion, which would tend to buffer any tendency toward a more acid pH. In addition, where water is in contact with tuff, considerable buffering would be supplied by the feldspar minerals, which readily exchange $\mathrm{Na}^{+}, \mathrm{K}^{+}$, and $\mathrm{Ca}^{++}$for $\mathrm{H}^{+}$ions. 13-17 The simultanecus presence of oxygen and neutral-to-alkaline $\mathrm{pH}$ could also reduce the production of carboxylic acids (see section 3.5).

Because of the existence of these opposing factors and the lack of a complete theoretical treatment of the glass-water interaction process, particularly under irradiation, John $\mathbf{R}$. Bates et al. of Argonne National Laboratory designed and carried out appropriate laboratory experiments to study the glass behavior under saturated tuff conditions with ganma irradiation. Some of the results have been reported.18,19

In order to apply these results to the prediction of glass behavior in a repository, it is necessary to understand the detailed mechanisms of the processes that occurred during the Bates et al. experiments. Therefore, using theory developed in earlier studies, in this paper we predict the radiation cnemical effects that would be expected to occur in the experimental configuration used by Bates et al. and compare these predictions with parameters observed by them.

The purpose of this work is to contribute to the development of a detailed understanding of the behavior of nuclear waste glass in a tuff repository. The repository can then be designed and its performance projected in such a way that the required reasonable assurance can be provided that radionuclide releases will be below the limits established by the Environmental protection Agency ${ }^{20}$ and the Nuclear Regulatory Commission ${ }^{21}$ (40CFRl9l and 10CFR60). 


\section{DESCRIPTION OF EXPERIMENTS AND RESULTS}

Bates et al. performed two sets of experiments to study the influence of gamma irradiation on the reaction of actinide-doped Savannah River Laboratory 165-frit nuclear waste glass in a saturated tuff environment. 18,19,22 These experiments consisted of irradiating small vessels containing various combinations of glass, tuff, water, and air with gamma rays for several time periods while maintaining an elevated temperature. The dissolved solutes and the glass surfaces were then analyzed.

The vessels were $304 \mathrm{~L}$ stainless steel parr reaction vessels, sealed with silicone rubber gaskets. They had a volume of $21.4 \mathrm{~cm}^{3}$. The nominal composition of $304 \mathrm{~L}$ stainless steel is given in Table 1 . The complete gasket composition was not measured. Bates found only $\mathrm{si}$ in an examination by energy-dispersive $x-r a y$ analysis, which was sensitive only to elements of $z \geq 11.22$ A later $150^{\circ} \mathrm{C}$ leaching experiment on the gasket material with $\mathrm{HNO}_{3}$ solution revealed only $\mathrm{Si}$ as a major constituent, with traces of $\mathrm{B}, \mathrm{Mg}$, and $\mathrm{Ca}$ also released. The vessels were machined using Trimsol, a soluble oil-type cutting fluid manufactured by the Master Chemical company. They were then polished using an aluminum oxide slurry. The vessels were ultrasonically cleaned in acetone, rinsed three times in high purity water, submerged in $90^{\circ} \mathrm{C}$ $18 \mathrm{HNO}_{3}$ solution for one hour, rinsed again three times with high purity water, and dried. The gaskets were heated to $90^{\circ} \mathrm{C}$ in high purity water for two hours, rinsed with high purity water, and dried.

The glass consisted of two types. The first was Savannah River Laboratory (SRL) 165 black frit to which U, Cs, and Sr had been added; it is referred to as SRL $U$ glass. The second was SRL U glass to which ${ }^{237} \mathrm{NP}$, ${ }^{239} \mathrm{Pu}$, and ${ }^{241_{\mathrm{Am}}}$ had been added; it is referred to as SRL A glass. In the first set of experiments, the glass was used both in the form of discs and powder. Discs, when used, were supported on $304 \mathrm{~L}$ stainless steel stands. In the second set of experiments, only discs were used. The composition of the glass used in the first set of tests is given in Table 2; the actinide composition was slightly different in the second set.

The first set of experiments used crushed Topopah Spring tuff from a drill hole at Fran Ridge near the Yucca Mountain site in Nevada (UE-25 $h$ \#, 173.0 to 173.6). We expect the major and minor element whole rock composition of this tuff to be similar to that reported by zielinski ${ }^{23}$ for drill. hole 
Table 1. Composition of AISI standard type 304L stainless steel. a

Element Weighe

Iron

Chromium

Nickel

Manganese

silicon

Phosphorus

Sulfur

Carbon
Balance (at least 65)

18.0-20.0

8. 0-12.0

2.0 maximun

1.0 naximum

0.045 maximur

0.03 maximum

0.03 maximum

a From American Society for Metals, Metals Bandbook (A.S.M., Metals Park, OH, 1980) 9 th ed., vol.3, p. 5. 
Table 2. Composition of SRL glasses used in farst set of tests. ${ }^{a}$

\begin{tabular}{|c|c|c|c|}
\hline \multirow[b]{3}{*}{ Component } & \multicolumn{3}{|c|}{ Analysis (weight 8 ) } \\
\hline & SRL $165 \mathrm{U} / \mathrm{A}$ & \multicolumn{2}{|c|}{ Black Frit } \\
\hline & ANL $^{b}$ & Ferroc & $\operatorname{MCC}^{\mathbf{d}}$ \\
\hline $\mathrm{Al}_{2} \mathrm{O}_{3}$ & 4.08 & 4.1 & 4.3 \\
\hline $\mathrm{B}_{2} \mathrm{O}_{3}$ & 6.76 & 6.8 & 6.8 \\
\hline $\mathrm{BaO}$ & 0.06 & & $<0.1$ \\
\hline $\mathrm{CaO}$ & 1.62 & 1.5 & 1.6 \\
\hline $\mathrm{Fe}_{2} \mathrm{O}_{3}$ & 11.35 & 12.3 & 11.7 \\
\hline FeO & 0.35 & & \\
\hline $\mathrm{K}_{2} \mathrm{O}$ & NA & & 0.2 \\
\hline $\mathrm{Li}_{2} \mathrm{O}$ & 4.18 & 4.7 & 4.8 \\
\hline Mgo & 0.70 & 0.8 & 0.6 \\
\hline Mno & 2.27 & 2.9 & 2.8 \\
\hline $\mathrm{Na}_{2} \mathrm{O}$ & 10.85 & 10.3 & 10.8 \\
\hline NiO & 0.85 & 0.9 & 0.8 \\
\hline $\mathrm{P}_{2} \mathrm{O}_{5}$ & & & 0.3 \\
\hline $\mathrm{SiO}_{2}$ & 52.86 & 54.1 & 51.6 \\
\hline $\mathrm{TiO}_{2}$ & 0.14 & & 0.2 \\
\hline Zno & 0.04 & & $<0.1$ \\
\hline $\mathrm{ZrO}_{2}$ & 0.66 & 1.2 & 0.7 \\
\hline $\mathbf{F}$ & NA & 0.06 & \\
\hline $\mathrm{Cl}$ & NA & 0.05 & \\
\hline $\mathrm{Pb}$ & $\mathbf{N A}$ & 0.05 & \\
\hline $237 \mathrm{NpO}_{2}$ & 0.008 & & \\
\hline${ }^{239} \mathrm{PuO}_{2}$ & $0.022^{\mathrm{e}}$ & & \\
\hline${ }^{24 I_{\mathrm{Am}_{2} \mathrm{O}_{3}}}$ & $0.00036^{\mathrm{e}}$ & & \\
\hline $\mathrm{U}_{3} \mathrm{O}_{8}$ & 0.96 & & \\
\hline $\mathrm{Cs}_{2} \mathrm{O}$ & 0.072 & & \\
\hline Sro & 0.11 & & \\
\hline others $^{f}$ & & & \\
\hline
\end{tabular}

NOTE: NA $=$ not analyzed.

arom J. K. Bates, D. F. Fischer, and T. J. Gerding, The Reaction of Glass in a Gamma Irradiated Saturated Tuff Environment. Part 1: SRL 165 Glass, Argonne National Laboratory, Argonne, IL, ANL-85-62 (1985).

$B$ Only SRL U glass was analyzed for all components. SRL A glass was analyzed for $237 \mathrm{~Np},{ }^{239} \mathrm{Pu}$, and $241_{\mathrm{Am}}$. The composition of both glasses are assumed to be the same, except for actinide elements.

C Black frit supplied to ANL by SRL, composition as determined by Ferro Corp.

d Black frit supplied by SRL to the MCC, composition as determined by MCC.

e Analysis by alpha spectrometry.

f $\mathrm{La}_{2} \mathrm{O}_{3}, \mathrm{Nd}_{2} \mathrm{O}_{3}, \mathrm{CeO}_{2}<0.05 ; \mathrm{MOO}_{3}<0.01$; and $\mathrm{Cr}_{2} \mathrm{O}_{3}<0.01$ weight 8 . 
USW-Gl, given in Table 3. The major mineral species present in this rock are quartz, cristobalite, and alkalai and plagioclase feldspars. The second set of experiments used discs of tuff from osw-Gl (1235.1 - 5 ft.).

"Equilibrated J-13 water" was so-called because it was prepared by heating water from Well J-13 near Yucca Mountain, together with crushed tuff, in a closed Teflon bottle for two weeks at $90^{\circ} \mathrm{C}$, filtering it, and storing it in a closed polypropylene container. Its composition should therefore be closer to what would exist in thermodynanic equilibriun with tuff at $90^{\circ} \mathrm{C}$ than the starting composition of J-13 water. The composition of the water used in the first set of experiments is shown in Table 4. The bicarbonate and potassium concentrations were not measured, so estinates were made based on anion-cation balance and previous analyses of solutions prepared in a sinilar way. The dissolved gas concentrations were calculated using Henry's Law, and the carbonate concentration was calculated assuning equilibriun constants are given in Table 5). The water composition was slightly different for the second set of experiments. Measured $\mathrm{pH}$ values for the starting water used in both sets are shown in Table 6. The difference between the two measured values probably results from nonequilibrtum concentrations of aissolved $\mathrm{CO}_{2}$.

The air was or'jnary laboratory air, the dry composition of which was probably near to that of standard dry air, as shown in Table 7. The humidity of the initial air was not controlled, but the air in the sealed capsules would have reached 1008 relative humidity because there was excess liquid water present, and there was sufficient time to rezci eqiilibriuri vapor pressure.

The gamma irradiation was provided by ${ }^{60}$ Co sources. In the first set of experiments, the dose rate (measured at the beginning of the ears:iments) was $2.0 \pm 0.2 \times 10^{5} \mathrm{rad} / \mathrm{hour}$ inside the vessels. In the second set of experimeists, the dose rate was $1.0 \pm 0.2 \times 10^{4} \mathrm{rad} /$ hour. The vessels were arranged reiative to the sources to achieve essentially the same dose rates in all the vessels. (Additional experiments at lower dose rates are underway.)

The vessels were placed inside an oven, the temperature of which was controlled at $90.0 \pm 0.5^{\circ} \mathrm{C}$. However, post-test measurements revealed that the astual vessel temperature was about $92^{\circ} \mathrm{C}$ for the first set of experiments. The vessels in the first set of experiments were run for time periods of 7,14 , 28 , and 56 days. The vessels in the second set were run for periods of 14,28 , 56, 91, and 182 days. There were 66 vessels in each set of experiments. 
Table 3. Conposition of Topopah Spring tuff (whole rock) from Hole osi-Gl, expressed as oxides."

\begin{tabular}{lc}
$\mathrm{SiO}_{2}$ & 75.2 \\
$\mathrm{Al}_{2} \mathrm{O}_{3}$ & 12.4 \\
$\mathrm{Z}_{2} \mathrm{O}$ & 4.8 \\
$\mathrm{Na}_{2} \mathrm{O}$ & 3.1 \\
$\mathrm{Fe}_{2} \mathrm{O}_{3}$ & 1.8 \\
$\mathrm{CaO}$ & 0.5 \\
$\mathrm{MgO}$ & 0.2 \\
$\mathrm{TiC}$ & \\
$\mathrm{MnO}$ & 0.1 \\
Loss on igmitic... & 0.06 \\
& 1.0 \\
\hline
\end{tabular}

a From R. A. Zielinski, Evaluation of Ash-flow Tuffs as Hosts for Radioactive Waste: Criteria Based on Selective Leaching of Manganese Oxides, U.S. Geological Survey, Denver, Co, Open File Report 63-480 (1983). 
Table 4. Composition of "Equilibrated J-13" water at $20^{\circ} \mathrm{C}$ (rirst set of experiments). a

\begin{tabular}{|c|c|c|}
\hline Species & Weight pgan & $\boldsymbol{n y}$ \\
\hline $\mathrm{Na}$ & 46.5 & 2.02 \\
\hline si & 34.4 & 1.22 \\
\hline $\mathbf{C a}$ & 9.08 & 0.23 \\
\hline K (estimated) & 6. & 0.15 \\
\hline $\mathrm{Mg}$ & 0.96 & 0.040 \\
\hline A1 & 0.63 & 0.023 \\
\hline $\mathbf{B}$ & 0.16 & 0.015 \\
\hline sr & 0.045 & 0.0005 \\
\hline $\mathbf{L i}$ & 0.044 & 0.006 \\
\hline Fe & 0.01 & 0.00018 \\
\hline U & 0.0024 & 0.00001 \\
\hline $\mathrm{HCO}_{3}^{-}$(estimated) & 122. & 2.00 \\
\hline $\mathrm{SO}_{4}^{-2}$ & 17.3 & 0.18 \\
\hline $\mathrm{NO}_{3}^{-}$ & 7.50 & 0.12 \\
\hline $\mathrm{Cl}^{-}$ & 7.15 & 0.20 \\
\hline $\mathrm{F}^{-}$ & 2.4 & 0.13 \\
\hline $\mathrm{NO}_{2}^{-}$ & not detected & - \\
\hline $\mathrm{co}_{3}^{-2}$ & 1.9 & 0.032 \\
\hline $\mathrm{CO}_{2}$ & 0.57 & 0.013 \\
\hline $\mathbf{N}_{2}$ & 15. & 0.53 \\
\hline $\mathrm{O}_{2}$ & 9.1 & 0.28 \\
\hline
\end{tabular}

a From J. R. Bates, D. F. Fischer, and T. J. Gerding, The Reaction of Glass in a Gamma Irrarizted Saturated Tuff Environment. Part 1: SRL 165 Glass, Argonne National : boratory, Argonne, IL, ANL-85-62 (1985) . 
Table 5. Parameters influencing composition of gas and liquid phases.

Parameter

liquid $\left(\mathrm{m}^{3} / \mathrm{kg}\right)$ value at $20^{\circ} \mathrm{C}$ Value at $90^{\circ} \mathrm{C}$

Reference

Specific volume of saturated

vapor $\left(m^{\dot{*}} / \mathrm{kg}\right)$

57.791

2.361

62

Eenry's Law constant of

$$
\mathrm{CO}_{2}(\mathrm{M} / \mathrm{Pa})
$$

$3.89 \times 10^{-7}$

$1 \times 10^{-7}$

63,64

Apparent first dissocjation

constant of $\mathrm{H}_{2} \mathrm{CO}_{3}$

(activity units)

$4.1 \times 10^{-7}$

$4.0 \times 10^{-7}$

44

(interpolated)

Second dissociation constant of $\mathrm{B}_{2} \mathrm{CO}_{3}$ (activity units)

$4.2 \times 10^{-11}$

$7.3 \times 10^{-11}$

44

Ion product of water $\left(\mathrm{M}^{2}\right)$

$6.8 \times 10^{-15}$

$3.5 \times 10^{-13}$

65

Henry's Law constant of
$\mathrm{N}_{2}(\mathrm{M} / \mathrm{Pa})$
$6.83 \times 10^{-9}$
$4.18 \times 10^{-9}$

Henry's Law constant of
$\mathrm{O}_{2} \quad(\mathrm{M} / \mathrm{Pa})$
$1.36 \times 10^{-8}$
$7.6 \times 10^{-9}$

63 
Table 6. Changes in compositions of gas anü liquid phases due to ha=ting, in vessels originally containing 16 ml of water.

\begin{tabular}{|c|c|c|}
\hline & \multicolumn{2}{|c|}{ Temperature } \\
\hline & $20^{\circ} \mathrm{C}$ & $90^{\circ} \mathrm{C}$ \\
\hline \multicolumn{3}{|l|}{ Gas phase } \\
\hline Volume $\left(\mathrm{m}^{3} \times 10^{6}\right)$ & 5.4 & 4.85 \\
\hline \multicolumn{3}{|l|}{ Pressures (kPa) } \\
\hline $\mathrm{N}_{2}$ & 78.2 & 106.5 \\
\hline $\mathrm{O}_{2}$ & 21.0 & 28.6 \\
\hline Ar & 0.9 & 1.3 \\
\hline $\mathrm{CO}_{2}$ & 0.03 & 0.42 \\
\hline $\mathrm{H}_{2} \mathrm{O}$ & 1.1 (508 R.H.) & 70.1 \\
\hline 'fotal & 101.23 & 206.92 \\
\hline
\end{tabular}

Liquid phase
Volume $\left(\mathrm{m}^{3} \times 10^{6}\right)$
16.0
16.55
pH (at temperature)
8.6 (calc.) 8.1$\}$ (meas.) 8.06 (calc.)

Concentrations of species

that are affected (M)
$\mathrm{CO}_{2}$
$1.3 \times 10^{-5}$
$4.2 \times 10^{-5}$
$\mathrm{HCO}_{3}^{-}$
$2.0 \times 10^{-3}$
$1.86 \times 10^{-3}$
$\mathrm{CO}_{3}^{-2}$
$3.2 \times 10^{-5}$
$1.5 \times 10^{-5}$
$\mathrm{N}_{2}$
$5.3 \times 10^{-4}$
$4.4 \times 10^{-4}$
$\mathrm{O}_{2}$
$2.8 \times 10^{-4}$
$2.2 \times 10^{-4}$ 
Table 7. composition of standard dry air. ${ }^{\mathbf{a}}$

\begin{tabular}{|c|c|c|c|}
\hline Species & Volume & 8 & Volume ppm \\
\hline $\mathrm{N}_{2}$ & $78.084 \pm$ & 0.004 & \\
\hline $\mathrm{O}_{2}$ & $20.946 \pm$ & 0.002 & \\
\hline $\mathrm{CO}_{2}$ & $0.033 \pm$ & 0.001 & \\
\hline $\mathbf{A r}$ & $0.934 \pm$ & 0.001 & \\
\hline $\mathrm{Ne}$ & & & $18.18 \pm 0.04$ \\
\hline $\mathrm{He}$ & & & $5.24 \pm 0.004$ \\
\hline $\mathbf{K r}$ & & & $1.14 \pm 0.01$ \\
\hline Xe & & & $0.087 \pm 0.001$ \\
\hline $\mathrm{H}_{2}$ & & & 0.5 \\
\hline $\mathrm{CH}_{4}$ & & & 2. \\
\hline $\mathrm{N}_{2} \mathrm{O}$ & & & $0.5 \pm 0.1$ \\
\hline
\end{tabular}

a From R. C. Weast and M. J. Astle, Eds., CRC Handkook of Chemistry and Physics, ô3d ed. (CRC Press, Boca Raton, FL, 1982). 
The volumes of "equilibrated J-13" water initially added to nost of the vessels ranged from 12.5 to $16.4 \mathrm{ml}$. In order to study the effect of changing the air-water ratio, the water volumes in two vessels in each set of experiments (G-113 and $G-114$ in the first set, and G-265 and G-266 in the second set) ranged only from 4.6 to $6.2 \mathrm{ml}$.

In the first set of experiments, some vessels were found to be pressurized to above atmospheric pressure after the irradiations, while in the second set they were not. Most of the 182-day vessels in the second set were found to have closure nuts that could be loosened by hand. To reduce damage to the gaskets, the closures in the second set had not been tightened as nuch as those in the first set, so later gasket creep may have loosened the seal somewhat. In two experiments in the first set (numbers G-113 and G-114) and in three in the second set (G-208, G-247, and G-248), the water was found to contain a flocculent, rust-colored precipitate, and the stainless steel was visibly corroded. In these cases, high levels of chloride ion and lower-than-normal pH vere also observed. Expertments $G-113$ and $G-114$ were tun with deionized water, while the others used "equilibrated J-13" vater. The solutions in G-208, G-247, and G-248 were found to be depleted in dissolved $\mathrm{NO}_{2}^{-}+\mathrm{NO}_{3}^{-}$and $\mathrm{SO}_{4}^{2-}$ compared to initial values. In the second set of experiments, the solution was observed to be yellow in several vther vessels. Films resembling oil films were observed in some vessels.

Analysis of the water was performed by inductively-coupled plasma optical emission spectroscopy, ion chromatography, and atomic fluorescence. In the second set, dissolved gas malysis was also performed, both by mass spectrometry of frozen samples and by the Van slyke method, which is:olves gas chromatography of a stirred solution. The $\mathrm{pH}$ was measured for all solutions. Bates et al. have published some of the data. 18,19 


\section{DIscussion}

\subsection{OVERVIEW}

In the experiments of Bates et al., two fluid media were in contact with each other: the gas phase, which started out as air, and the liquid phase, which started out in most cases as "equilibrated J-13" water having the dissolved species shown in Table 4. As time progressed, interactions occurred between the fluid phases and the other materials, namely the stainless steel, the glass, and the tuff. From a radiation chemistry standpoint, this is a very complex system. Radiation chemical experiments are usually performed on highly purified systems with a minimum number of constituents in essentially inert vessels. A precise theoretical analysis of this system would require a time-dependent computer model incorporating at least two compartments to represent the two fluid phases. Within each compartment, provision would need to be made for inputting the yields of the primary radiolytic species and calculating their reactions by means of coupled rate equations. The sicnificant reactions and their rates would have to be known for both phases at the temperature of interest. Provisions would have to be made for transport of species between the two phases, and the equations governing such transport wouid have to be supplied. Significant interactions tetween the fluid and solid phases would also have to be understood well enou:h to be modeled mathematically.

At present, the capability to do all of this is not available, so far as I know. Researchers at Chalk River have made progress on understanding the irradiation of dry air and have published results of computer simulations. 24-26 Tokunaga and Suzuki have qualitatively described the radiation chemistry of moist $\mathrm{N}_{2}-\mathrm{O}_{2}$ mixtures. 27 Busi et al. have presented a computer model for mixtures of $\mathrm{N}_{2}, \mathrm{O}_{2}, \mathrm{H}_{2} \mathrm{O}$, and $\mathrm{CO}_{2} \cdot{ }^{28}$ To my knowledge, however, modeling of the radiation chemistry of a gaseous system incorporating significant proportions of $\mathrm{N}_{2}, \mathrm{O}_{2}, \mathrm{H}_{2} \mathrm{O}$, and $\mathrm{H}_{2}$ (from radiolysis), such as was present in the Bates et al. experiments, has nut been performed.

Likewise, computer models of liguid water systems have been constructed by researchers from Argonne, ${ }^{29}$ Harwell, ${ }^{30}$ Chalk River, ${ }^{31}$ Riso, ${ }^{32}$ Battelle Pacific Northwest Laboratories, ${ }^{33}$ and Battelle Columbus Laboratories. ${ }^{34}$ However, these models have incorporated only a few solutes. To my knowleage, 
modeling has not been performed on a bicarbonate water, although Swedish researchers have discussed the importance of bicarbonate as a scavenger in irradiated groundwater. 35

Provision for transport of $\mathrm{H}_{2}$ and $\mathrm{O}_{2}$ between a gas and a liquid phase has been made by some of these researchers. I an not aware of any conputer models that have incorporated transport of oxides of nitrogen over time. Burns et al. have modeled the corrosion behavior of stainless and mild steels in the presence of irradiated air and demineralized or distilled water. 36 However, to my knowledge, interactions with nuclear waste glass and rock have not been modeled in a radiation chemistry code.

Since a thoroughgoing computer model of the system of interest was not available, I elected to perform an approximate analysis of the radiation chemistry, considering only the dominant reactions. In this report, I first present an overview of the major features and the expected observable results. I rext consider the radiation chemistry in greater detail, beginning with the fluid phases in isolation. I then consider transport of species between the fluid phases and important interactions with the solid phases. With this background, I calculate specific observable parameter changes and compare them with the results of Bates et al. for cases in which corresponding measurements were made.

\subsection{CHANGES IN COMPOSITION DUE TO HEATING}

In this paper I take the irradiation temperature to be $90^{\circ} \mathrm{C}$. Differences in behavior at $92^{\circ} \mathrm{C}$, as actually used in the first set of experiments by Bates et al., are expected to be minor. When a closed system containing air and an aqueous solution such as "equilibrated J-13" water is heated from room temperature to $90^{\circ} \mathrm{C}$, a number of changes occur that affect the composition of the two phases. The important parameters and their values at $20^{\circ} \mathrm{C}$ and $90^{\circ} \mathrm{C}$ were given in Table 5. The main effects of heating on the vessels that originally contained $16 \mathrm{ml}$ of water and $5.4 \mathrm{ml}$ of air are shown in Table 6 . Note that: water evaporates to produce a higher vapor pressure; the remaining liquid water expands and reduces the gas space; a small amount of $\mathrm{CO}_{2}$ moves from the liquid to the gas phase because of its reduced solubility; the bicarbonate and carbonate concentrations drop slightly to maintain equilibrium; the dissolved $\mathrm{CO}_{2}$ concentration rises slightly because of the 
increased vapor pressure; and the $\mathrm{N}_{2}$ and $\mathrm{O}_{2}$ concentrations drop slightly because of decreased solubility. My calculations of these values assumed constant zoncentrations for cations other than ${\mathrm{B}^{+}}^{+}$I considered this valid because the water was previously "equilibrated" at $90^{\circ} \mathrm{C}$. Ionization of silicic acid was not included; its effect would be to lower the pH only slightly. It should be noted that a small amount of gas leakage may have occurred from the 182-day vessels in the second set of experiments by Bates et al. This would have had the effect of reducing the relative concentrations of $\mathrm{N}_{2}, \mathrm{O}_{2}, \mathrm{Ar}, \mathrm{CO}_{2}$, and later $\mathrm{H}_{2}$, with respect to water vapor, in the gas phase.

In the following discussion I focus first on the so-called "blank" experiments that started with $16 \mathrm{ml}$ of water and did not contain rock or glass.

\subsection{OVERVIEW OF MAJOR FEATURES AND EXPECTED OBSERVABLE RESULTS}

Past research has shown that the stable products of low-dose-rate irradiation of moist air are gaseous nitric acid $\left(\mathrm{HNO}_{3}\right)$, nitrous oxide $\left(\mathrm{N}_{2} \mathrm{O}\right)$, and a small amount of ozone $\left(\mathrm{O}_{3}\right) .6$ In a liquid water phase, the primary products of irradiation are $\mathrm{OH}, \mathrm{e}_{\mathrm{aq}}^{-}, \mathrm{H}_{3} \mathrm{O}^{+}, \mathrm{H}_{2} \mathrm{O}_{2}, \mathrm{H}, \mathrm{H}_{2}$, and $\mathrm{HO}_{2}$ (Table 8), 37 If three conditions are met (i.e., if the water is of high purity, the container is inert and sealed, and only gamma irradiation is used), then the free radical products $\mathrm{H}, \mathrm{OH}, \mathrm{e}_{\mathrm{aq}}^{-}$, and $\mathrm{HO}_{2}$ will react with the molecular products $\mathrm{H}_{2}$ and $\mathrm{H}_{2} \mathrm{O}_{2}$ in such a way that the result is small steadystate concentrations of $\mathrm{H}_{2} \mathrm{O}_{2}, \mathrm{H}_{2}$, and $\mathrm{O}_{2}$ dissolved in the water, and there is no net decomposition of the water as a function of time. However, in the Bates et al. experiments there were several initially-dissolved species that have significant reaction rates with the primary free radical products. In addition, the species produced by irradiation of the gas phase would dissolve in the liquid phase, and could then also interact with the primary free radicals. Interactions would also take place between the free radicals and the stainless steel vessels. It appears from previous investigations that there would be four significant results of these processes:

1. A net decomposition (radiolysis) of water into $\mathrm{H}_{2}$ and $\mathrm{O}_{2}$ would occur as a function of time.

2. Nitrogen would be fixed and added to the liquid phase, appearing at the end of the experiments as nitrate $\left(\mathrm{NO}_{3}^{-}\right)$and nitrite $\left(\mathrm{NO}_{2}^{-}\right)$ions. 
Table 8. Primary products of gama irradiation of liquid water for pH 5 to $9 .^{\text {a }}$

Product

G

$\begin{array}{lc}\mathrm{H}_{2} \mathrm{O} & -4.08 \\ \mathrm{OH} \text { (hydroxyl radical) } & 2.72 \\ \mathrm{e}_{\mathrm{ag}}^{-} \text {(hydrated electron) } & 2.63 \\ \mathrm{H}_{3} \mathrm{O}^{+} \text {(hydronium ion) } & 2.63 \\ \mathrm{H}_{2} \mathrm{O}_{2} \text { (hydrogen peroxide) } & 0.68 \\ \mathrm{H} \text { (hydrogen atom) } & 0.55 \\ \mathrm{H}_{2} \text { (hydrogen molecule) } & 0.45 \\ \mathrm{HO}_{2} \text { (perhydroxyl radical) } & 0.026\end{array}$

a From J. W. T. Spinks and R. J. Woods, An Introduction to Radiation Chemistry (Wiley, New York, 1976), 2nd ed. 
3. An equivalent amount of hydrogen ions would be produced in the solution, tending to lower the $\mathrm{pH}$ against the buffering action of the dissolved bicarbonate as well as that of the rock and glass, where present.

4. Colloidal Fe(III) iron-containing substances would become suspended in the solution as a result of vessel wall reactions.

\subsection{GAS PHASE}

If we use the gas composition at $90^{\circ} \mathrm{C}$ in Table 7 and assume that the gamma rays would interact with the species listed in proportion to their fractions of the total electron density (a valid assumption for compton interactions, which are dominant here), we find that the energy should be absorbed in about the following proportions:

$\mathrm{N}_{2}-578, \mathrm{H}_{2} \mathrm{O}-268$, and $\mathrm{O}_{2}-178$, other gases negligible.

The production rates of the initial radiolytic products (ions, free radicals, excited molecules, and electrons) can be determined by weighting the yields, G, for the pure gases by these proportions. The yield (in radiation chemistry) is defined as the number of molecules of a particular species that are created or destroyed when $100 \mathrm{eV}$ of energy is absorbed from radiation. $\mathrm{G}_{X}$ represents the primary yield of species $x, i . e .$, the yield evaluated before any subsequent reactions take place. $G(X)$ represents the final or observed $y$ ield of species $x$ in an experiment in which reactions may have occurred after the initial production of the species. $G(X)$ is measured, and $G_{X}$ is inferred or measured in experiments designed such that $G_{X}$ will be equal to $G(X)$.

Willis and Boyd have summarized available data to evaluate the yields for the various species formed in irradiation of inorganic gases. 25 For the gases that are important here, the species include $\mathrm{N}_{2}^{+}, \mathrm{N}^{+}, \mathrm{N}, \mathrm{N}_{2}^{*}, \mathrm{O}_{2}^{+}, \mathrm{O}^{+}, 0$, $\mathrm{O}_{2}^{\star}, \mathrm{H}_{2} \mathrm{O}^{+}, \mathrm{H}^{+}, \mathrm{OH}^{+}, \mathrm{H}, \mathrm{OH}, \mathrm{H}_{2} \mathrm{O}^{*}, \mathrm{H}_{2}$, and $\mathrm{e}^{-}$. Some of these species are produced in more than one energy state, so the total description of the system becomes quite complex.

The ionic species produced in the irradiation would undergo a series of reactions with other species present. 27,28 The results would be additional free radical and molecular species. The free radicals in turn would interact with each other and with other species to produce $\mathrm{HNO}_{3}, \mathrm{~N}_{2} \mathrm{O}$, and $\mathrm{O}_{3}$, as observed by Jones. 6 Intermediate species in this process are thought to include $\mathrm{NO}$, $\mathrm{NO}_{2}$, and possibly $\mathrm{N}_{2} \mathrm{O}_{4} \cdot \quad\left(\mathrm{NO}_{3}\right.$ and $\mathrm{N}_{2} \mathrm{O}_{5}$ are believed to be formed 
in irradiation of dry air, but not moist air.) Further behavior is affected by interaction with the liquid phase.

\subsection{LIQUIJ PHASE}

For aqueous solutions with total solute concentrations less than about $0.1 \mathrm{M}$, interactions of the radiation only with the water need to be consideied. 37 When gamma rays interact with water, they excite electrons and produce ionization by the photoelectric and conpton effects. The recolling electrons deposit their energy by interacting with electrons in other molacules. The result is that excitation and ionization are produced in concentrated regions called spurs and tracks. This results in formation within these regions of the species $\mathrm{H}_{2} \mathrm{O}^{+}, \mathrm{e}^{-}$, and $\mathrm{H}_{2} \mathrm{c}^{*}$. Reaction of $\mathrm{H}_{2} \mathrm{O}^{+} \mathrm{with}$ water molecules then produces $\mathrm{H}_{3} \mathrm{O}^{+}$ions and $\mathrm{OH}$. Dissociation of excited molecules produces $\mathrm{H}, \mathrm{OH}, \mathrm{H}_{2}$, and $\mathrm{O}$. Some electrons are captured by $\mathrm{H}_{3} \mathrm{O}^{+}$ ions, producing $\mathrm{H}_{2} \mathrm{O}$ and $\mathrm{H}$. Some of the caged $\mathrm{H}$ and $\mathrm{OH}$ radicals recombine to form water. The electrons becone solvated, forming $\mathrm{e}_{\mathrm{aq}}^{-}$All of the above events occur within about $10^{-11}$ seconds of the initial interaction of the gamina ray with the water.

At about $10^{-10}$ seconds, the free radical species can diffuse far enough to undergo significant numbers of reactions with each other. This occurs first: within the spurs and tracks, because of proximity. These reactions produce $\mathrm{H}_{2} \mathrm{O}, \mathrm{H}_{2}$, and $\mathrm{H}_{2} \mathrm{O}_{2}$ within the spurs and tracks within a total elapsed time of $10^{-8}$ seconds. So iong as the concentrations of reactive solutes in the water are less than about $10^{-3} \mathrm{~N}$, the solutes will not significantly interfere with the above processes. ${ }^{37}$ As can be seen from Tables 4 and 6 , the water in these experiments satisfieg this criterion. At this stage, the products of the irradiation are called "primary products," and their yields are as shown in Table 8 for gamma irradiation of liquid water at roon temperature in the $\mathrm{pH}$ range from about 5 to 9 . At $90^{\circ} \mathrm{C}$, the values might differ by as much as 108 , as deduced from the work of Hochanadel and Ghormley. 38

During the period between $10^{-6} \mathrm{sec}$ and sbout $1 \mathrm{sec}$ after an indtial gamma interaction, the free radicals $\left(\mathrm{OH}_{,} \mathrm{H}, \mathrm{e}_{\partial \mathrm{q}^{-}}^{-}\right.$and $\left.\mathrm{HO}_{2}\right)$ and the molecuiar species $\left(\mathrm{H}_{2}\right.$ and $\left.\mathrm{H}_{2} \mathrm{O}_{2}\right)$ are able to diffuse from spurs and tracks into the bulk of the solution. There the free radicals interact with each other, with the 
molecular species, or with reactive solutes, if present. In the case of gama irradiation of very high purity (triply distilled) water in an inert, closed container, small concentrations of $\mathrm{H}_{2} \mathrm{O}_{2}, \mathrm{H}_{2}$, and $\mathrm{O}_{2}$ build up, the latter fron decomposition of $\mathrm{H}_{2} \mathrm{O}_{2}$. Since there are insignificant concentrations of solutes, the free radicals are able to react with the molecular species to reform water, and there is no net decomposition of water over time.

When reactive solutes are present in the water, as is the case with "equilibrated J-13" water, there is a competition for reaction with the free radicals. They undergo second order reactions, the rates of which are given by equations of the form

$$
\text { Rate } \frac{\text { moles }}{1 \text { iter-sec }}=k \frac{\text { liter }}{\text { moles-sec }} \times\left[R_{1}\right] \frac{\text { moles }}{\text { liter }} \times\left[R_{2}\right] \frac{\text { moles }}{\text { liter }}
$$

where $\left[R_{1}\right]$ is the concentration of free radical $R_{1}$, and $\left[R_{2}\right]$ is the concentration of another reactive species, either another free radical, a molecular product, or a solute.

In orjer to predict what the dominant reactions of each free radical will be, we need to know the concentrations of these other species and the reaction rate constants. The rate constants for the significant reactions that take place in pure water and common aqueous solutions have been measured and tabulated. The list given in Table 9 summarizes the reactions and rate constants presented by several authors. As can be seen, there is essential agreement between authors. The values shown are for $25^{\circ} \mathrm{C}$. The free radical reaction rates are not expected to be significantly different at $90^{\circ} \mathrm{C}$, because the free radicals in water radiolysis are highly reactive, having low energies of activation for their reactions. 7,29 The reactions tend to be diffusion limited, rather than activation limited. The pR values for $\mathrm{H}_{2} \mathrm{O}, \mathrm{HO}_{2}$, and $\mathrm{H}_{2} \mathrm{O}_{2}$ do shift with temperature. The $\mathrm{H}_{2} \mathrm{O} \mathrm{pK}$ shift is the only significant one for our purposes, and it has been taken into account.

A measure of the relative importance of solutes compared to free radicals in reactions with free radicals can be obtained from a knowledge of the maximum concentrations that could be reached by the free radicals during a continuous irradiation of pure water, i.e., in the absence of reactive solutes. These concentrations are fixed by the reactions of free radicals with free radicals. For a maximum dose rate of $2 \times 10^{5} \mathrm{Mrad} / \mathrm{hour}$, as used in these experiments, the upper limit to the free radical concentrations is in the range of $10^{-9} \mathrm{M} \cdot{ }^{37}$ of the solutes found in "equilibrated $\mathrm{J}-13^{\mathrm{N}}$ water in 
Table 9. Reactions and rata constants for pure water at $25^{\circ} \mathrm{C}$.

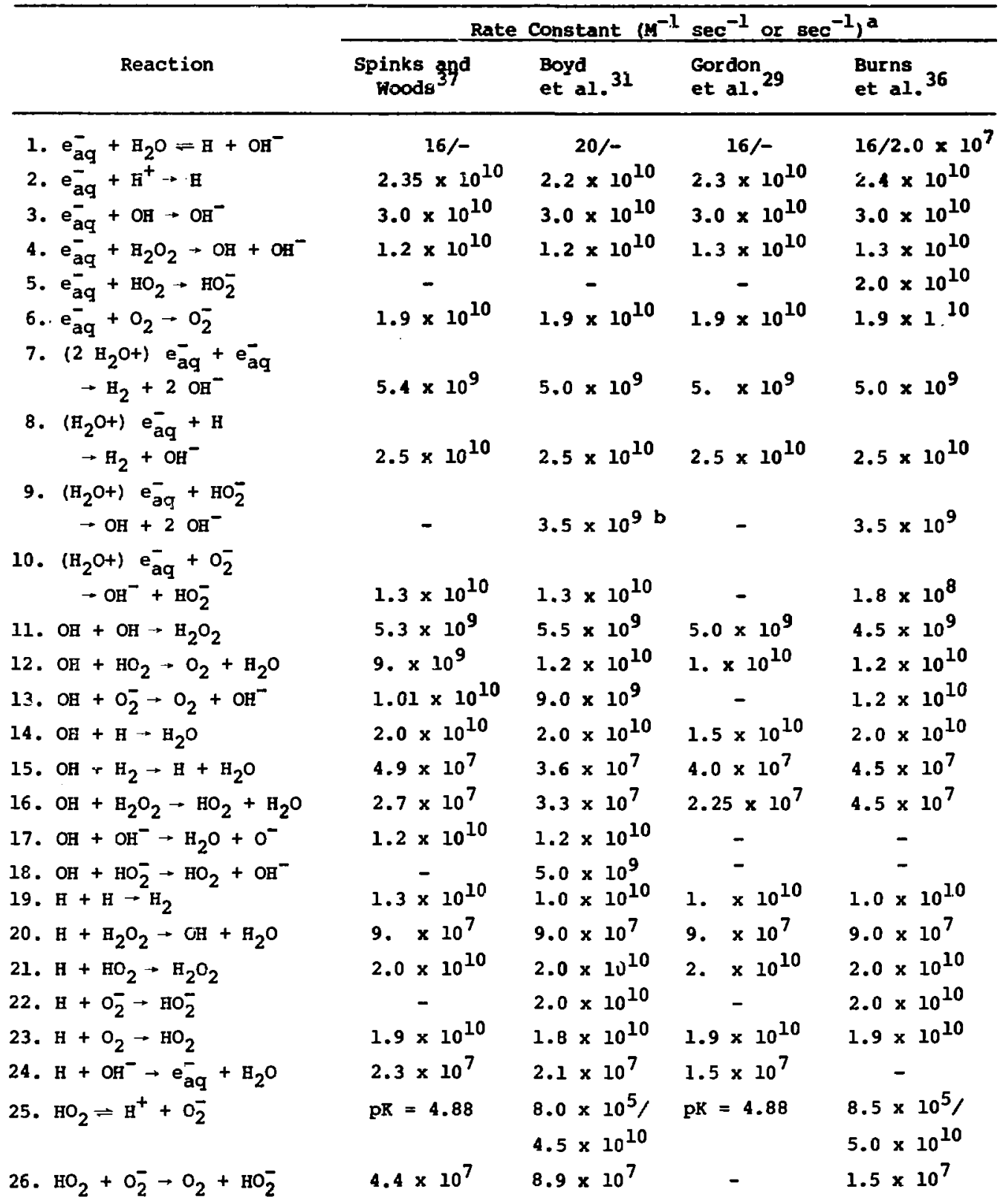


Table 9. Continued.

27. $\mathrm{HO}_{\tilde{\mathrm{z}}}+\mathrm{HO}_{2} \rightarrow \mathrm{H}_{2} \mathrm{O}_{2}+\mathrm{O}_{2} \quad 2.5 \times 10^{6} \quad 2.0 \times 10^{6} \underset{\text { (for } \mathrm{pH}=6.5 \text { ) }}{1.6 \times 10^{6}} 2.7 \times 10^{6}$

28. $\left(2 \mathrm{~B}_{2} \mathrm{O}+\right) \mathrm{O}_{2}^{-}+\mathrm{O}_{2}^{-}$

$$
\rightarrow \mathrm{O}_{2}+\mathrm{B}_{2} \mathrm{O}_{2}+2 \mathrm{OH}^{-}
$$

29. $\mathrm{H}^{+}+\mathrm{OH}^{-} \Rightarrow \mathrm{H}_{2} \mathrm{O}$

$\begin{array}{cc}- & - \\ 1.43 \times 10^{11} / & 1.43 \times 10^{11} \\ - & 2.6 \times 10^{-5}\end{array}$

30. $\mathrm{OH}^{-}+\mathrm{H}_{2} \mathrm{O}_{2} \rightleftharpoons \mathrm{HO}_{2}^{-}+\mathrm{H}_{2} \mathrm{O}$

31. $\mathrm{H}^{+}+\mathrm{HO}_{2}^{-}=\mathrm{H}_{2} \mathrm{O}_{2}$

32. $\mathrm{O}^{-}+\mathrm{H}_{2} \mathrm{C} \rightarrow \mathrm{OH}+\mathrm{OH}^{-}$

33. $\mathrm{O}^{-}+\mathrm{O}_{2} \rightarrow \mathrm{O}_{3}^{-}$

34. $\mathrm{O}^{-}+\mathrm{H}_{2} \rightarrow \mathrm{H}+\mathrm{OH}^{-}$

35. $\mathrm{O}^{-}+\mathrm{H}_{2} \mathrm{O}_{2} \rightarrow \mathrm{H}_{2} \mathrm{O}+\mathrm{O}_{2}^{-}$

36. $\mathrm{HO}_{2}^{-}+\mathrm{O}^{-} \rightarrow \mathrm{OB}^{-}+\mathrm{O}_{2}^{-}$

37. $\mathrm{O}_{3}^{-}+\mathrm{H}_{2} \mathrm{O}_{2} \rightarrow \mathrm{O}_{2}^{-}+\mathrm{O}_{2}+\mathrm{B}_{2} \mathrm{O}$

$(0.17$ to

$2.9 \times 10^{9}$

8. $\times 10^{7}$

$5.3 \times 10^{8}$

$2.0 \times 10^{10} /$

$3.56 \times 10^{-2}$

38. $\mathrm{O}_{3}^{-}+\mathrm{HO}_{2}^{-} \rightarrow \mathrm{O}_{2}^{-}+\mathrm{O}_{2}+\mathrm{OH}^{-}$

39. $\mathrm{O}_{3}^{-} \rightarrow \mathrm{O}_{2}+\mathrm{O}^{-}$

40. $\mathrm{O}_{3}^{-}+\mathrm{H}_{2} \rightarrow \mathrm{O}_{2}+\mathrm{B}+\mathrm{OH}^{-}$

41. $\mathrm{O}_{2}^{-} \rightarrow$ products

42. $\mathrm{o}_{2}^{-}+\mathrm{O}_{2}^{-} \rightarrow \mathrm{O}_{2}^{2-}+\mathrm{O}_{2}$

43. $\mathrm{CH}=\mathrm{O}^{-}+\mathrm{H}^{+}$
$5.0 \times 10^{7}$

$\mathrm{pR}=11.9$
$1.7 \times 10^{6}$

$3.0 \times 10^{9}$

$8.0 \times 10^{7}$

$2.0 \times 10^{8}$

$8.0 \times 10^{8}$

$1.6 \times 10^{6}$

$8.9 \times 10^{5}$

$3.0 \times 10^{2}$

$(\mathrm{pB}=13)$

$2.5 \times 10^{5}$

$6.0 \times 10^{-2}$

$(\mathrm{pH}=13)$
0

$1.438 \times 10^{11} /$

$2.6 \times 10^{-5}$

$1.0 \times 10^{8} /$

$1.022 \times 10^{4}$

$2.0 \times 10^{10} y$

NOTE: Where two values are shown, the first is for the forward reaction and the second is for the reverse reaction.

Second order rates are given as $\mathrm{M}^{-1} \sec ^{-1}$; first order rates as $\sec ^{-1}$, for $k$, not $2 \mathrm{k}$.

Reaction is actually given as $\mathrm{e}_{\mathrm{ag}}^{-}+\mathrm{HO}_{2}^{-} \rightarrow \mathrm{O}^{-}+\mathrm{OH}^{-}$. 
significant concentrations (Table 4), $\mathrm{HCO}_{3}^{-}, \mathrm{NO}_{3}^{-}, \mathrm{Cl}^{-}, \mathrm{CO}_{3}^{-2}, \mathrm{CO}_{2}$, and $\mathrm{O}_{2}$ are known to have significant reaction rates (i.e., greater than $10^{7} \mathrm{H}^{-1} \sec ^{-1}$ ) with one or another of the free radical species. Since all these solutes have concentrations greater than $10^{-5} \mathrm{H}$, they can clearly dominate the free-radical/free-radical reactions in competing for free radicals.

In addition to reacting with dissolved solutes, the free radicals can also react with suspended colloids. Burns et al. found that Fe(III) iron oxide colloid formed upon gamma irradiation of distilled or deionized water and air in stainless steel vessels, and they believe that reactions between the free radicals and this colloid gave rise to the decomposition of water they observed. 36

In the following discussion, I consider each of the free radical species in turn and determine what its doninant initial reactions $w i$ th the solutes would be in the solution (described in Tables 4 and 6) using measured reaction rates reported in the literature. (Note that several solutes are present from the beginning, whereas the colloids form during irradiation.)

As can be seen in Table 8 , the hydroxyl radicals (OF) are the products formed with the highest yield. Their initial reactions would prinarily be with chloride ions:

$$
\begin{aligned}
& \mathrm{OH}+\mathrm{Cl}^{-} \rightarrow \mathrm{ClOH}^{-} \quad \mathrm{k}_{44}=4.3 \times 10^{9} \mathrm{H}^{-1} \mathrm{sec}^{-1} \text { (see Ref. 39), } \\
& \mathrm{ClOH}^{-}+\mathrm{H}^{+} \rightarrow \mathrm{Cl}+\mathrm{H}_{2} \mathrm{O} \quad \mathrm{k}_{45}=2.1 \times 10^{10} \mathrm{M}^{-1} \mathrm{sec}^{-1} \text { (see Ref. 39). } \\
& \mathrm{Cl}+\mathrm{Cl}^{-} \rightarrow \mathrm{Cl}_{2}^{-} \quad \mathrm{k}_{46}=2.1 \times 10^{10} \mathrm{~m}^{-1} \mathrm{sec}^{-1} \text { (see Ref. 39). }
\end{aligned}
$$

The product $\mathrm{k}_{44}\left[\mathrm{Cl}^{-}\right]$would be $2 \times 10^{5} \mathrm{sec}^{-1}$ initially.

The hydroxyl radicals $(\mathrm{OH})$ would also react $w i t h$ bicarbonate and carbonate ions:

$$
\begin{array}{ll}
\mathrm{OH}+\mathrm{HCO}_{3}^{-} \rightarrow \mathrm{CO}_{3}^{-}+\mathrm{H}_{2} \mathrm{O} & \mathrm{k}_{47}=1.25 \times 10^{7} \mathrm{M}^{-1} \mathrm{sec}^{-1} \text { (see Ref. 37), } \\
\mathrm{OH}+\mathrm{CO}_{3}^{-2} \rightarrow \mathrm{CO}_{3}^{-}+\mathrm{OH}^{-} & \mathrm{k}_{48}=4.1 \times 10^{8} \mathrm{M}^{-1} \mathrm{sec}^{-1} \text { (see Ref. 37). }
\end{array}
$$

The product $\mathrm{k}_{47}\left[\mathrm{HCO}_{3}^{-}\right]$is $2.3 \times 10^{4} \mathrm{sec}^{-1}$. For $\mathrm{CO}_{3}^{-2}$, the product is $6.1 \times 10^{3}$. The carbonate radical $\mathrm{CO}_{3}^{-}$reacts with the superoxide ion $\mathrm{O}_{2}^{-}$(the origin of which is discussed below), and the product is thought to be $\mathrm{CO}_{5}^{-2}$ (see Ref. 40):

$$
\mathrm{CO}_{3}^{-}+\mathrm{O}_{2}^{-}-\mathrm{CO}_{5}^{-2} \quad \mathrm{k}_{49}=(1.5 \text { to } 15) \times 10^{8} \mathrm{M}^{-1} \mathrm{sec}^{-1} \text { (see Rer̂s. 40-43). }
$$

This species in turn is thought to decay by a first order process:

$$
\mathrm{CO}_{5}^{-2} \rightarrow \mathrm{CO}_{3}^{-2}+\mathrm{O}_{2} \text { (see Ref. 40) (Reaction 50). }
$$

The carbonate ion would then associate to form bicarbonate at pH 8 :

$$
\mathrm{HCO}_{3}^{-} \neq \mathrm{H}^{+}+\mathrm{CO}_{3}^{-2} \quad \mathrm{pK}_{51}=10.1 \text { at } 90^{\circ} \mathrm{C} \text { (see Ref. } 44 \text { ). }
$$


Since the $\mathrm{O}_{2}^{-}$has originated as $\mathrm{O}_{2}$ (see below), and one $\mathrm{H}_{3} \mathrm{O}^{+}$ion is formed as a primary product for each $e_{a q}^{-}$radical formed in the irradiation, there would be no net chemical change from this sequence.

At the beginning of the experiments, there was no measurable nitrite in the solution, but some was found at the end, so I will consider its reactions. When nitrite was present, it would also have had a significant reaction rate with of radicals:

$$
\mathrm{OH}+\mathrm{NO}_{2}^{-}-\mathrm{NO}_{2}+\mathrm{OH}^{-} \quad \mathrm{k}_{52}=6.20 \times 10^{9} \mathrm{~m}^{-1} \mathrm{sec}^{-1} \text { (see Ref. 37). }
$$

At the end of the "blank" experiments that received the highest doses, the nitrite concentration was $2.1 \times 10^{-4} \mathrm{M}$. The product $\mathrm{k}_{52}\left[\mathrm{No}_{2}^{-}\right]$was then $1.3 \times 10^{6} \mathrm{sec}^{-1}$, which means this reaction would dominate those mentioned above after $\mathrm{NO}_{2}^{-}$had built up. The $\mathrm{NO}_{2}$ thus formed would react with water to produce nitrate and nitrite ${ }^{45}$ :

$2 \mathrm{NO}_{2}+\mathrm{H}_{2} \mathrm{O} \rightarrow 2 \mathrm{H}^{+}+\mathrm{NO}_{3}^{-}+\mathrm{NO}_{2}^{-}$(Reaction 53).

As the irradiation proceeded, $\mathrm{H}_{2}$, formed as a prinary product, would begin to build up and would compete with these other species for reaction with OH radicals. It would continue to build up until its rate of reaction with $\mathrm{OH}$ equaled its rate of formation. To achieve steadystate concentration, the $\mathrm{H}_{2}$ would have to react with about one-sixth of the of radicals, because $\mathrm{G}_{\mathrm{H}_{2}}$ is about one-sixth of $\mathrm{G}_{\mathrm{OH}}$ (see Table 8 ). To have had a reaction rate equal to one-fifth of the sum of the reaction rates of $\mathrm{Cl}^{-}$and $\mathrm{BCO}_{3}^{-}$, which were the competitors at the beginning of the experiment, the $\mathrm{H}_{2}$ concentration would have had to have been $9.1 \times 10^{-4} \mathrm{M}$, which requires an $\mathrm{H}_{2}$ pressure above the solution of $130 \mathrm{kPa}$. Such a pressure would not have been reached before the $\mathrm{NO}_{2}^{-}$concentration was observed to $\mathrm{rise}$ significantly, so $\mathrm{H}_{2}$ would have continued to build up to higher pressures as competition increased for the OH. To have had a reaction rate equal to one-fifth that of the $\mathrm{NO}_{2}^{-}, \mathrm{Cl}^{-}$, and $\mathrm{HCO}_{3}^{-}$, which were the solute competitors at the end of the experiment, the $\mathrm{H}_{2}$ concentration would have had to have been $6 \times 10^{-3} \mathrm{M}$, which would have required an $\mathrm{H}_{2}$ pressure above the solution of about $850 \mathrm{kPa}$ at $90^{\circ} \mathrm{C}$. This means that relatively high $\mathrm{H}_{2}$ pressures would have been required before the $\mathrm{H}_{2}$ pressuie would have leveled off. For comparison, Gray and simonson found that gamma radiolysis of Permian Basin saturated brine at $75^{\circ} \mathrm{C}$ produced a total steadystate gas pressure $\left(\mathrm{H}_{2}\right.$ plus $\left.\mathrm{O}_{2}\right)$ of about $10 \mathrm{MPa} .{ }^{46}$ This is a much more concentrated solution than "equilibrated J-13" water. 
In their experiments mentioned earlier, Burns et al. found that gama irradiation of air-saturated, triply distilled or demineralized water in stainless steel vessels at 30 to $50^{\circ} \mathrm{C}$ produced total steadystate pressures of 300 to $450 \mathrm{kPa}$, including $\mathrm{H}_{2}, \mathrm{O}_{2}$, and $\mathrm{N}_{2} \cdot 36$ As noted, they invoked the presence of a colloid to explain the results. If colloid-free radical reactions were significant in conparison to solute-free radical reactions at the end of the the Bates et al, experiments, then the $\mathrm{H}_{2}$ pressure required for steadystate would have been significantly higher than $850 \mathrm{kPa}$.

The radical species produced with the next highest yield is the hydrated electron $\left(e_{a q}^{-}\right)$. In oxygenated solution, superoxide ions are formed:

$$
\mathrm{e}_{\mathrm{aq}}^{-}+\mathrm{O}_{2} \rightarrow \mathrm{O}_{2}^{-} \quad \mathrm{k}_{6}=1.9 \times 10^{10} \mathrm{M}^{-1} \mathrm{sec}^{-1} \text { (see Ref. 37). }
$$

In the Bates et al. experiments that had $16 \mathrm{ml}$ of water at the outset, the initial concentration of $\mathrm{O}_{2}$ in the liquid phase would have been about $2.2 \times 10^{-4} \mathrm{M}$ (Table 6 ). The product $k_{6}\left[\mathrm{O}_{2}\right]$ would then have been about $4 \times 10^{6} \mathrm{sec}^{-1}$ for this reaction.

Competing reactions would have been those with nitrate, dissolved $\mathrm{CO}_{2}$ ' chlorine atoms, and ferric lons:

$$
\begin{array}{ll}
\mathrm{e}_{\mathrm{aq}}^{-}+\mathrm{NO}_{3}^{-} \rightarrow \mathrm{NO}_{3}^{-2}\left(-\mathrm{NO}_{2}+2 \mathrm{OH}^{-}\right) & \mathrm{k}_{54}=1.1 \times 10^{10} \mathrm{M}^{-1} \mathrm{sec}^{-1} \text { (see Ref. 37), } \\
\mathrm{e}_{\mathrm{aq}}^{-}+\mathrm{CO}_{2} \rightarrow \mathrm{CO}_{2}^{-} & \mathrm{k}_{55}=7.7 \times 10^{9} \mathrm{M}^{-1} \mathrm{sec}^{-1} \text { (see Ref. 37), } \\
\mathrm{e}_{\mathrm{aq}}^{-\mathrm{CI} \rightarrow \mathrm{Cl}^{-}} & \left.\mathrm{k}_{56}+1.0 \times 10^{9} \mathrm{M}^{-1} \mathrm{sec}^{-1} \text { (see Ref. } 7\right), \\
\mathrm{e}_{\mathrm{aq}}^{-}+\mathrm{Fe}^{+3} \rightarrow \mathrm{Fe}^{+2} & \mathrm{k}_{57}=5 \times 10^{10} \mathrm{M}^{-1} \mathrm{sec}^{-1} \text { (see Ref. 37). }
\end{array}
$$

Using the initial $\mathrm{NO}_{3}^{-}$concentration (Table 4$), \mathrm{k}_{54}\left[\mathrm{NO}_{3}^{-}\right]$would have been $1.3 \times 10^{6} \mathrm{sec}^{-1}$, and $k_{55}\left[\mathrm{CO}_{2}\right]$ would have been about $3.2 \times 10^{5} \mathrm{sec}^{-1}$. The very low $\mathrm{Fe}^{+3}$ concentration would have made it a negligible contributor at the beginning of the experiments, and the pH buffering would have kept its concentration low. It is difficult to calculate the steadystate $\mathrm{Cl}$ concentration, but the maximum possible value of $k_{56}[\mathrm{Cl}]$ if only the initially dissolved $\mathrm{Cl}^{-}$is considered would have been $2 \times 10^{5} \mathrm{sec}^{-1}$. This indicates that nearly 708 of the $\mathrm{e}_{\mathrm{aq}}^{-}$would have reacted with $\mathrm{O}_{2}$, about 228 would have reacted with $\mathrm{NO}_{3}^{-}$, and about 68 would have reacted with $\mathrm{CO}_{2}$ at the outset. As the irradiation proceeded, the $\mathrm{O}_{2}$ would have built up, taking a larger share of the $\mathrm{e}_{\mathrm{aq}}^{-}$reactions, and colloids also could have become important reactants. As discussed above, the $\mathrm{O}_{2}^{-}$produced would react with carbonate radicals, producing $\mathrm{O}_{2}$. It would also react with $\mathrm{OH}$ by Reaction 13, again producing $\mathrm{O}_{2}$ :

$$
\mathrm{OH}=\mathrm{O}_{2}^{-} \rightarrow \mathrm{Gn}^{--}+\mathrm{O}_{2} \quad \mathrm{k}_{13}=1.0 \times 10^{10} \mathrm{H}^{-1} \mathrm{sec}^{-1} \text { (see Ref. 37). }
$$

Burns et al. predict that the $\mathrm{O}_{2}^{-}$would also react significantly with the stainless steel vessel walls. $36^{2}$ 
The $\mathrm{HO}_{2}$ radicals produced as primary species would dissociate to $\mathrm{O}_{2}^{-}$(at $\mathrm{pH}$ above about 5) and would react in these sane ways. The $\mathrm{NO}_{2}$ produced would react with water to form $\mathrm{NO}_{2}^{-}$and $\mathrm{NO}_{3}^{-}$, as discussed earlier (Reaction 53). The carboxyl radicals $\left(\mathrm{CO}_{2}^{-}\right)$would remain dissociated at $\mathrm{pH} 8$ :

$$
\mathrm{COOH} \rightarrow \mathrm{H}^{+}+\mathrm{CO}_{2}^{-} \quad \mathrm{pR}_{58}=3.3 \pm 0.3 \text { (see Ref. 47). }
$$

In oxygenated solution, the charge transfer reaction

$$
\mathrm{CO}_{2}^{-}+\mathrm{O}_{2} \rightarrow \mathrm{CO}_{2}+\mathrm{O}_{2}^{-} \quad \text { (Reaction 59) }
$$

has been found to be fast, 47 and for $\left[\mathrm{o}_{2}\right]=10^{-4} \mathrm{M}$, it would overwhelm the dimerization reaction to form oxalate:

$$
\mathrm{CO}_{2}^{-}+\mathrm{CO}_{2}^{-} \rightarrow \mathrm{C}_{2} \mathrm{O}_{4}^{-2} \quad 2 \mathrm{k}_{60}=1 \times 10^{9} \mathrm{M}^{-1} \mathrm{sec}^{-1} \text { (see Ref. 48) }
$$

so that very little oxalate would be formed. Furthermore, in solutions containing $\mathrm{O}_{2}$, oxalate is destroyed by reactions with of radicals

$$
\mathrm{C}_{2} \mathrm{O}_{4}^{-2}+\mathrm{OH} \cdot \mathrm{C}_{2} \mathrm{O}_{4}^{-}+\mathrm{OH}^{-} \quad \mathrm{K}_{61}=6 \times 10^{6} \mathrm{M}^{-1} \mathrm{sec}^{-1} \text { (see Ref. 49) }
$$

which are followed by reactions with oxygen:

$$
\mathrm{C}_{2} \mathrm{O}_{4}^{-}+\mathrm{O}_{2} \rightarrow \mathrm{O}_{2}^{-}+2 \mathrm{CO}_{2} \quad \text { (Reaction 62) (see Ref. 49). }
$$

In the presence of $\mathrm{Ca}^{++}$ions, as in "equilibrated $\mathrm{J}-13^{\text {" water, oxalate }}$ (if present) would precipitate as calcium oxalate, which has a solubility of about $10^{-4} \mathrm{M}$ (see Ref. 50). The fact that the observed $\mathrm{Ca}^{++}$concentration in solution did not decrease from its original value of $2.3 \times 10^{-4} \mathrm{M}$ supports the contention that little oxalate was formed. In the experiments of Hasselstron and Henry, oxalic acid was produced by irradiation of bicarbonate and, necessarily, $\mathrm{CO}_{2}$ solutions. 51 Apparently there was insufficient oxygen to oxidize the carboxyl radicals, so that the Gimerization to form oxalate was free to proceed. Their solutions were irradiated in polyethylene bags, and they did not perform gas analysis.

If the $\mathrm{CO}_{2}^{-}$became associated to form $\mathrm{COOH}$, it could react to form formate ions or formic acid ${ }^{47}$ :

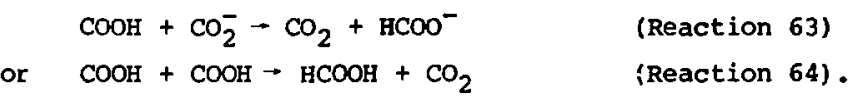

The formate and formic acid thus formed would remain soluble. production of formate is not likely in the bulk of the liquid phase, because the pH there was buffered near 8 , and the $\mathrm{CO}_{2}^{-}$would not associate. However, it might have occurred in the liquid film around the top of the gas space, where nitric acid production and deposition could drive the $\mathrm{pH}$ down in the absence of buffering. It should be noted that past experiments in which formate was produced from dissolved $\mathrm{CO}_{2}$ were either oxygen-free ${ }^{8-10}$ or were driven to low 
pH by simultaneous formation of nitric acid. 11,12 Either of these conditions would prevent the carboxyl radicals from transferring charge to oxygen, and thus make them available to form formate or oxalate.

The other primary free radical produced in the irradiation is the hydrogen atom. At the outset, its only significant reactions wowd be with dissolved oxygen and with $\mathrm{Cl}$ produceo in the ofi reaction mentioned earlier:

$$
\begin{array}{ll}
\mathrm{H}+\mathrm{O}_{2} \cdot \mathrm{HO}_{2} & \mathrm{k}_{23}=1.9 \times 10^{10} \mathrm{M}^{-1} \mathrm{sec}^{-1} \text { (see Ref. 37). } \\
\mathrm{H}+\mathrm{Cl} \cdot \mathrm{H}^{+}+\mathrm{Cl}^{-} & \mathrm{k}_{65}=5.0 \times 10^{9} \mathrm{M}^{-1} \mathrm{sec}^{-1} \text { (see Ref. 7). }
\end{array}
$$

The $\mathrm{HO}_{2}$ would dissociate to $\mathrm{O}_{2}^{-}$and react as described earlier to produce $\mathrm{O}_{2}$. The products $k_{23}\left[\mathrm{O}_{2}\right]$ and $k_{65}[\mathrm{Cl}]$ would be $4.2 \times 10^{6} \mathrm{sec}^{-1}$ and $1 \times 10^{6} \mathrm{sec}^{-1}$ (maximum), respectively. As the irradiation proceeded, nitrite would be formed as discussed earlier, and $\mathrm{H}$ atons could react with it:

$$
\mathrm{H}+\mathrm{NO}_{2}^{-} \cdot \mathrm{NO}+\mathrm{OH}^{-} \quad \mathrm{k}_{66}=1 \times 10^{9} \mathrm{H}^{-1} \mathrm{sec}^{-1} \text { (see Ref. 37). }
$$

At the end of the highest dose experiments, $k_{66}\left[\mathrm{No}_{2}^{-}\right]$was about $10^{5} \sec ^{-1}$ for this reaction. In the Bates et al. experiments, the $o_{2}$ concentration as a function of time probably represents a balance between production by water radiolysis and loss to reaction rith the stainless steel. Data from corrosion experiments indicate that reaction with the metal in these experiments would account for only a small part of the $\mathrm{o}_{2}$ produced by radiolysis. 52 This result was also found by Burns et al. 36 It therefore appears that the $o_{2}$ concentration would $\mathrm{rise}$, and $\mathrm{O}_{2}$ would dominate the $\mathrm{H}$ reactions during the entire experiment. The No probably would react rapidly with an oxidizing species in the water to again form $\mathrm{NO}_{2}$ and then would react with water to form $\mathrm{NO}_{2}^{-}$and $\mathrm{NO}_{3}^{-}$.

Having discussed the fates of the primary free radical species, we turn now to the molecular species $\mathrm{H}_{2}$ and $\mathrm{H}_{2} \mathrm{O}_{2}$. As discussed already, $\mathrm{H}_{2}$ can be expected to $r$ ise in pressure to at least $850 \mathrm{kPa}$ if the irradiation proceeds for a time long enough to reach steadystate conditions. In pure water, the $\mathrm{H}_{2} \mathrm{O}_{2}$ concentration is limited by reactions with $\mathrm{e}_{\mathrm{aq}}^{-} \mathrm{H}_{\mathrm{p}}$ and $\mathrm{OH}$, as noted above. Where these were effectively scavenged by solutes, $\mathrm{H}_{2} \mathrm{O}_{2}$ could be expected to build up. We have observed this in room temperature irradiation corrosion experiments that included only a glass vessel, J-13 water, and a stainless steel electrode. 53 However, since $\mathrm{H}_{2} \mathrm{O}_{2}$ is tr.ermodynamically unstable at all temperatures, it would thermally decompose at elevated temperatures and in the presence of materials that are catalytic for the decomposition reaction

$$
2 \mathrm{H}_{2} \mathrm{O}_{2} \rightarrow 2 \mathrm{H}_{2} \mathrm{O}+\mathrm{O}_{2} \quad \text { (Reaction 67). }
$$


Dissolved $\mathrm{Fe}^{+3}$ is known to be an effective catalyst, producing measurable effects at concentrations less than 0.1 ppm. 54 solid materials found in the tuff and glass may also catalyze this decomposition. Manganese oxide, which is found in the tuff, is one example of a known effective catalyst. $54 \mathrm{H}_{2} \mathrm{O}_{2}$ could also react with $\mathrm{Cl}$ :

$$
\mathrm{H}_{2} \mathrm{O}_{2}+\mathrm{Cl} \rightarrow \mathrm{H}^{+}+\mathrm{Cl}^{-}+\mathrm{HO}_{2} \quad \mathrm{k}_{68}=5.0 \times 10^{9} \mathrm{M}^{-1} \mathrm{sec}^{-1} \text { (see Ref. 7). }
$$

It seems probable that the $\mathrm{H}_{2} \mathrm{O}_{2}$ concentrations in these experiments were linited to small values by these reactions. The decomposition of $\mathrm{B}_{2} \mathrm{O}_{2}$ would give rise to oxygen gas, and the amount would be essentially one-half the anount of hydrogen given off, since the stoichiometry of the solution must continue to correspond closely to $\mathrm{H}_{2} \mathrm{O}$.

\subsection{GAS AND LIQUID PHASES CONSIDERED TOGETHER}

Because gas and liquid phases are in contact in the experiments of Bates et al., we must consider exchange of gaseous species between them during the irradiation. As noted in Section 3.4, the stable products formed during irradiation of the gas phase would be gaseous $\mathrm{ENO}_{3}, \mathrm{~N}_{2} \mathrm{O}$, and $\mathrm{O}_{3}$. In addition, there would be transient species such as $\mathrm{NO}, \mathrm{NO}_{2}$, and probably $\mathrm{N}_{2} \mathrm{O}_{4}$ that could conceivably dissolve in the liquid phase before they reacted to form $\mathrm{HNO}_{3}$ or $\mathrm{N}_{2} \mathrm{O}$. To determine which of these processes would be more rapid, we would need to calculate the lifetimes of these transient species by modeling the gas phase reaction sequence and then compare them to typical diffusion times to reach the liquid phase in the geometry used. This has not been done in this analysis because of the complexity of the system and the uncertainty of some aspects of the reaction sequence. However, even though the detailed mechanism is not established, experimental measurements have been performed on the two-phase air-water system. 5,55 Burns et al. ${ }^{7}$ have derived an equation describing the fixation of nitrogen as a function of time and other parameters for a sealed system:

$$
N=2 C_{0} R\left[1-\exp \left(-1.45 \times 10^{-5} \mathrm{GDt}\right)\right]
$$

where $\mathrm{N}$ is the concentration of $\mathrm{HNO}_{3}$ in the water in moles/liter at time $t$,

$\mathrm{C}_{0}$ is the initial concentration of $\mathrm{N}_{2}$ in the air in moles/liter,

$R$ is the ratio of the volume of air to the volume of water,

$\mathrm{G}$ is the yield (= 1.9) (using Harwell data as interpreted by Burns et al. ${ }^{7}$ ),

$\mathrm{D}$ is the dose rate in $\mathrm{Mrad} / \mathrm{hr}$, and

$t$ is the time in hours. 
For total deses much less than $3.6 \times 10^{4} \mathrm{Mrad}$, this equation reduces to $\mathrm{N}=2.90 \times 10^{-5} \mathrm{C}_{\mathrm{O}}$ RGDt.

(Eq. 3)

In the Bates et al. experiments, the maximum dose was $269 \mathrm{Mrad}$, so this form of the equation is adequate. As can be seen, the production of fixed nitrogen is directly proportional to $R$ and to the dose $D t$.

Although Equation 2 appears to have been derived using unbuffered, initially neutral water, I have applied it to the Bates et al. data on the grounds that the total fixed nitrogen concentration coes not appear to be very sensitive to $\mathrm{pH}$ under oxidizing conditions. 55 This probably results from the facts that the oxidation occurs in the gas phase and that once the nitrogen is fixed as nitrate or nitrite in the solution, it tends to remain in the solution, because to escape, it would have to be reduced to No, and this species is rapidly oxidized in an irradiated solution regardiess of the pH, forming $\mathrm{NO}_{2}$ and then $\mathrm{NO}_{2}^{-}$and $\mathrm{NO}_{3}^{-}$. The movement of fixed nitrogen is thus a one-way process under these conditions.

The $\mathrm{N}_{2} \mathrm{O}$ produced in the gas phase may dissolve in the liquid phase and be destroyed by reactions with $e_{a q}^{-}$:

$\mathrm{e}_{\mathrm{aq}}^{-}+\mathrm{N}_{2} \mathrm{O} \rightarrow \mathrm{N}_{2}+\mathrm{O}^{-}\left(+\mathrm{H}^{+} \rightarrow \mathrm{OH}\right) \quad \mathrm{k}_{69}=8.7 \times 10^{9} \mathrm{M}^{-1} \sec ^{-1}$ (see Ref. 38). Ozone rapidly decomposes upon dissolution in water at high temperatures and neutral or high $\mathrm{pH}$. The mechanism is not completely understood, but the formation of oH radicals is a significant aspect of it. 56

The gases generated in the liquid phase in excess of their solubilities must move to the gas phase. These include $\mathrm{H}_{2}, \mathrm{O}_{2}$, and the $\mathrm{N}_{2}$ resulting from the above $\mathrm{N}_{2} \mathrm{O}$ reaction.

\subsection{INTERACTIONS WITH THE SOLID PHASE}

As mentioned earlier, we expect that some oxidation of the stainless steel will occur, although it should be limited by the formation of a protective layer under the $\mathrm{pH}$ and redox conditions of most of these experiments. Dissolution of iron and chromium should be slight, so long as the $\mathrm{pH}$ remains near $8.57 \mathrm{Nickel}$ and manganese do have some solubility under these conditions, but their dissolution should be limited by the protective layer.

Burns et al. have gamma irradiated sealed cylinders made of Types 304 and 321 stainless steel, containing air and either triply distilled or 
demineralized water. ${ }^{36}$ Temperatures in their experiments ranged between 30 and $50^{\circ} \mathrm{C}$, and dose rates were between 0.15 and $2 \mathrm{Mrad} / \mathrm{hour}$, with doses extending up to $1000 \mathrm{Mrad}$. They analyzed the gases inside the cylinders and monitored their pressures. The amount of corrosion occurring was calculated from the deficit in oxygen gas observed compared to one-half the observed hydrogen. They explained their gas composition results on the basis of the formation of an Fe(III) iron-oxide colloid, which they observed at the end of some of their experiments.

As noted in the description of the Bates et al. results in Section 2, yellow solutions were found in several vessels, and rusty precipitates were found in others. It seems clear that an iron-containing colloid was formed in the Bates et al. experiments as well. Flocculation of the colloid may account for the anion depletion.

Stainless steel is not a very efficient catalyst for the decomposition of $\mathrm{H}_{2} \mathrm{O}_{2}$. The stainless steel surface could act as a substrate for precipitation of species from the solution that may have dissolved from the glass or tuff and later become less soluble because of changing solution conditions or changes in the chemical form or oxidation state of the species. The stainless steel could also affect the nitrite-nitrate ratio in the solution, because of the ability of iron to reduce nitrate to nitrite. In unirradiated open system corrosion experiments with J-13 water and stainless steel, we have observed the gradual disappearance of fixed nitrogen from the water completely, over a period of a few months. 58 We presume that this disappearance results from the reduction of nitrate to nitrits and then to $\mathrm{N}_{2} \mathrm{O}$, which is a relatively inert gas and could diffuse out of an open system.

The tuff rock would serve as a powerful $\mathrm{pH}$ buffer for the solution by exchanging $\mathrm{Na}^{+}, \mathrm{K}^{+}$, or $\mathrm{Ca}^{+2}$ ions for $\mathrm{H}^{+}$ions. This has been observed extensively in the past with feldspar minerals, as mentioned in the Introduction (Section 1). The manganese oxide and iron in the tuff could serve as catalysts for $\mathrm{H}_{2} \mathrm{O}_{2}$ decomposition, as rentioned in section 3.5. Transient primary radical species formed near the surface of the tuff could react with it directly, particularly with species such as iron, which has more than one possible oxidation state. Dissolution of some minerals from the tuff could be expected, as well as precipitation of others.

Reports by Bates and oversby ${ }^{18}$ and Bates et al. ${ }^{19}$ describe the behavior of the glass. This behavior includes dissolution and precipitation of various 
species. As is true for the tuff, we expect that the iron and manganese oxide in the glass could serve as decomposition catalysts for $\mathrm{H}_{2} \mathrm{O}_{2}$, and the iron could also enter into reactions with primary free radical species.

In the Bates et al. experiments, the SRL A glass was doped with actinides (as noted in Section 2), and the resulting alpha emission necessarily delivered ionizing radiation to the liquid in contact with the glass surface. However, approximate calculations indicate that the dose rate would have been less than $10^{3} \mathrm{rad} /$ hour at the interface for the doping level used, compared to the $10^{4}$ and $2 \times 10^{5} \mathrm{rad} / \mathrm{hr}$ gamma dose rates absorbed by the solutions in the experiments. When one considers in addition that only a layer of liquid of the order of $10^{-3} \mathrm{~cm}$ thick received the alpha dose, it is clear that the alpha contribution to the bulk irradiation of the solution was small compared to the gamma contribution in these experiments. However, near the surface of the glass in the lower dose rate experiments, the alpha irradiation could have caused a significant increase in the concentrations of the molecular products $\mathrm{H}_{2}$ and $\mathrm{H}_{2} \mathrm{O}_{2}$, since their yields are considerably higher in alpha radiolysis than in gamma radiolysis. 37 Bates noted that in both sets of experiments the SRL A glass reacted slightly faster than the SRL U glass. 18,19,22 This may have been a consequence of alpha radiolysis.

\subsection{DECOMPOSITION OF MATER}

As has already been alluded to in section 3.5, one effect of gamma irradiation on an aqueous solution containing solutes that can react with the primary free radical species is decomposition of water into $\mathrm{H}_{2}$ and $\mathrm{O}_{2}$.

In the Bates et al. experiments, it appears that the solutes present initially were in high enough concentration to prevent the radicals from reacting significantly with the molecular products in the bulk of the solution, but they would not have been so high as to interfere with the formation of the molecular products in the tracks and spurs. It thus appears that the initial water decomposition yield $G\left(-g_{2} 0\right)$ should have been approximately equal to $G_{H_{2}}$, i.e., 0.45. Applying this value to the "blank" experiments irradiated at $2 \times 10^{5} \mathrm{rad} / \mathrm{hr}$ for the maximum time of 56 days, giving a total dose of 269 Mrad, the exposure of 16 grams of water would have led to the decomposition to $\mathrm{H}_{2}$ and $\mathrm{O}_{2}$ of $3.6 \times 10^{-2} \mathrm{grams}$, or 2 millimoles, assuming no back reactions occurred. Using the ideal gas law and a gas space (at room temperature) of 
$5.4 \mathrm{ml}$, this amount of gas would have developed a pressure increase of over $1.3 \mathrm{MPa}$ after cooling to room temperature. As noted in section 3.5, the back reaction of $\mathrm{H}_{2}$ with oH radicals would actually limit the $\mathrm{B}_{2}$ pressure to about $850 \mathrm{kPa}$ at $90^{\circ} \mathrm{C}$, if reactions with colloids are not considered. Adding an $\mathrm{O}_{2}$ pressure equal to half this value would produce a total of about 1.28 MPa at $90^{\circ} \mathrm{C}$. This would be equivalent to $1.03 \mathrm{MPa}$ at $20^{\circ} \mathrm{C}$. This indicates that at the highest dose in the Bates et al. experiments steady-state gas pressures should have been achieved. The total pressure, jncluding the original air, would have been $1.13 \mathrm{MPa}$ at $20^{\circ} \mathrm{C}$. Bates et al. observed pressurization of the higher dose vessels (as noted in section 2), although the pressures were not measured. 19

In their second set of experiments, Bates et al. applied a maximum dose of about $43.7 \mathrm{Mrad}$, or less than one-sixth of that in the first set. This would help to account for the lack of observed pressurization in the second set. It should be noted also that some loss of gases through or around the silicone rubber gasket may have occurred in this set, as mentioned in Section 2, and some reaction of oxygen with the stainless steel also occurred; both of these processes would have reduced the pressure. The time available for these processes to occur was over three times as long for the longest duration irradiations in the second set of experiments as for those in the first set. Although calibrated dissolved gas analyses were not complete at the time this paper was written, Bates reports that considerable amounts of hydrogen were found (in addition to nitrogen, oxygen, and carbon dioxide) in the second set of experiments, and that the relative amounts found were consistent with the hypothesis that some gas leakage occurred in the second set. 22

\subsection{FIXATION OF NITROGEN}

As noted in section 3.6, Equation 2 (Burns et al. ${ }^{7}$ ) predicts that the amount of radiation-fixed nitrogen should be linear with dose in this range. The equation also predicts that the amount should be proportional to $R$, the ratio of gas to liquid volume. Since $R$ varied between vessels, it is necessary to correct for this in making comparisons. Before such a correction can be applied, the value of the - nitial total fixed nitrogen concentration must be subtracted from the measured fixed nitrogen data. 
An initial plot of the data for the $2 \times 10^{5} \mathrm{rad} / \mathrm{hour}$ experiments showed that there was considerable scatter and that subtraction of the reported initial value $\left(7.6 \mathrm{ppm}\right.$ or $\left.1.22 \times 10^{-4} \mathrm{M} \mathrm{NO}_{3}^{-}\right)$did not result in a best $\mathrm{fit}$ line passing through the origin. Nevertheless, it was assumed that such a line must obtain, and that the points at 28 and 56 days were the most reliable, being highest above the initial value. Consequently, the value chosen for the initial total fixed nitrogen concentration was that which resulted in a straight line passing through the origin and the average values at 28 and 56 days, uncorrected for $R$ value. This turned out to be $1.65 \times 10^{-4}$ $\mathrm{M}$ (or $10.2 \mathrm{ppm}$ ) $\mathrm{NO}_{3}^{-}$. This initial value was subtracted from the data, and the correction for $\mathrm{R}$ was then applied.

The resulting data for the $2 \times 10^{5} \mathrm{rad} /$ hour experiments are plotted in Fig. 1 , normalized to $R=0.337$, which was the value at room temperature for the vessels containing water and air only. The solid line represents the prediction of the Burns et al. equation, indicating $1.6 \times 10^{-4} \mathrm{M}$ of additional fixed nitrogen concentration for a dose of $269 \mathrm{Mrad}$. The agreement is satisfactory, considering the uncertainties in the data and in the yield. Each data point is an average from two replicate experiments. In some cases replicates differed by more than 15\% in reported total fixed nitrogen concentrations.

Bates et al. give the precision of anion analyses as \pm 58 , and the accuracy also as \pm 58 . The uncertainty in dose was \pm 108 . The uncertainty in $G$ value was not given by Burns et al. $7^{7}$ but a value of \pm 158 would not be unreasonable, based on the dose uncertainty in the reference they cite. 55 Because of these uncertainties, it is not possible tc determine whether there were significant differences in nitrogen fixation rates among the various vessels. All that can be said is that the rates were essentially as predicted by the Burns et al. equation.

For the second set of experiments, the dose was less than one-sixth as great as it was for the first set. The predicted increase in fixed nitrogen concentration would thus be $2.6 \times 10^{-5}$ moles/liter for those vessels having low gas-to-liquid volume ratios. The observed total fixed nitrogen concentration does not show a significant increase over the course of the experiments, and the scatter in values is of the order of 1 to $3 \times 10^{-5}$ moles/liter. As can be seen from Fig. 1 , the predicted increase is less than the precision of the data and would therefore not be expected to be seen. 


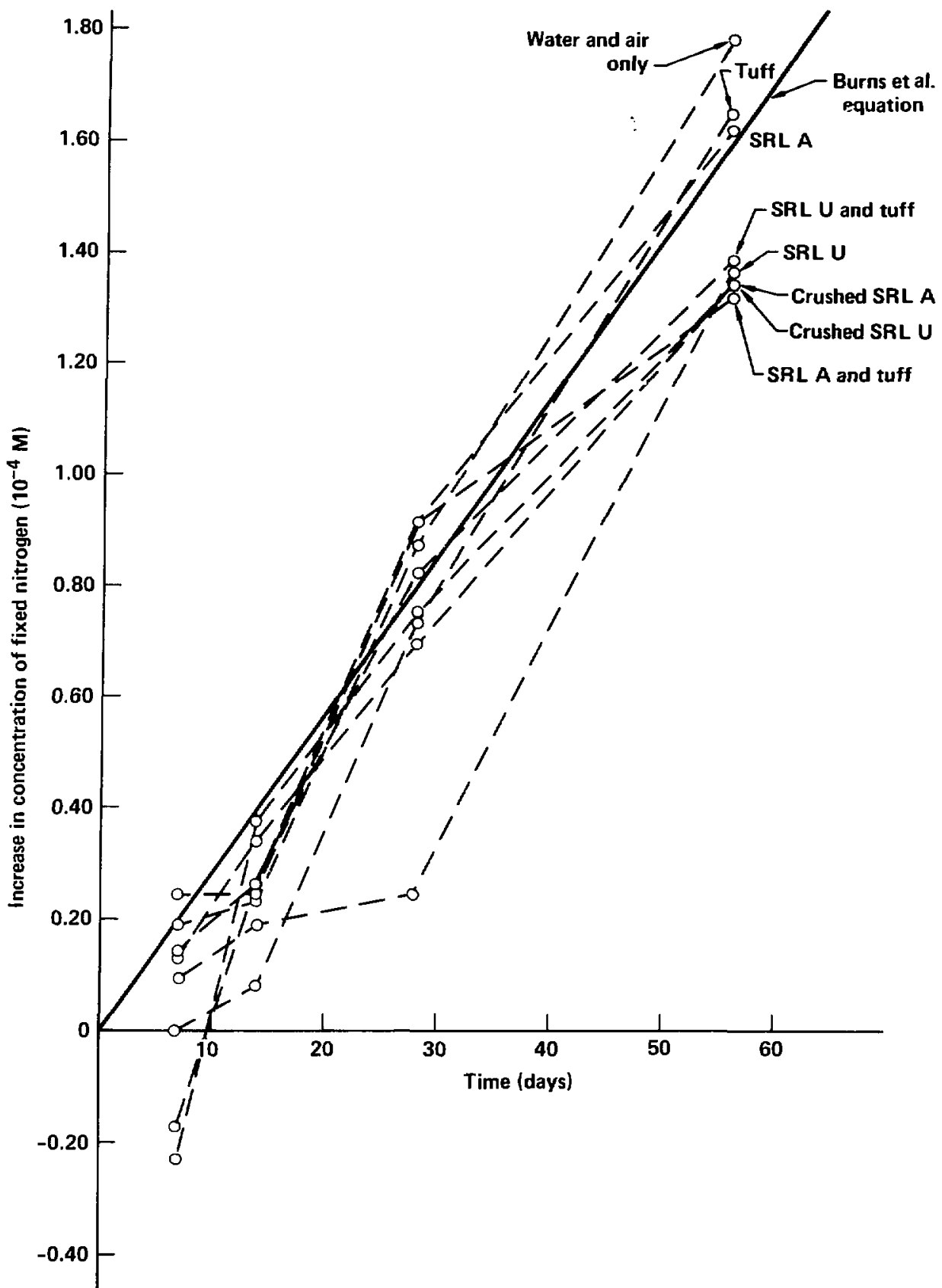

Figure 1. Nitrogen fixation in $2 \times 10^{5} \mathrm{rad} / \mathrm{hr}$ experiment. 
The production of nitrite and nitrate in the aqueous solution was accompanied by an equimolar production of hydrogen ions. For the experinents with $16 \mathrm{ml}$ of water and a dose of 269 Mrads, the total added $\mathrm{H}^{+}$would therefore have amounted to $1.6 \times 10^{-4}$ moles/1iter. Since the initial bicarbonate concentration was more than 10 times this level, we would expect it to have buffered the added $\mathrm{B}^{+}$and thus to have prevented a large $\mathrm{pH}$ change. This is in fact what is observed in the Bates et al. data. By contrast, experiments performed by others using deionized or distilled water have shown shifts of $\mathrm{pH}$ into the 3-4 range. ${ }^{2}$ The changes in pil due to nitrogen fixation for the second set of experiments by Bates et al. should be even less significant, since the maximum dose was one-sixth as large.

\subsection{NITRITE-NITRATE RATIO}

Most past experiments involving irradiation of two-phase air-water systems that have been reported in the literature have made use of deionized or distilled water. In such cases the solution is unbuffered, and generation of nitric acid drives the pH so low that any nitrite present tends to associate with $\mathrm{H}^{+}$to form nitrous acid, $\mathrm{HNO}_{2}\left(\mathrm{pR}_{\mathrm{a}}=5.22\right.$ at $\left.25^{\circ} \mathrm{C}\right) .45$ This acid is thermaliy unstable and decomposes according the the reaction:

$$
3 \mathrm{HNO}_{2} \rightarrow \mathrm{H}^{+}+\mathrm{NO}_{3}^{-}+2 \mathrm{NO}+\mathrm{H}_{2} \mathrm{O} \text { (Reaction 70) (see Ref. } 59 \text { ). }
$$

It also reacts with $\mathrm{H}_{2} \mathrm{O}_{2}$ :

$$
\mathrm{H}_{2} \mathrm{O}_{2}+\mathrm{HNO}_{2} \rightarrow \mathrm{H}^{+}+\mathrm{NO}_{3}^{-}+\mathrm{H}_{2} \mathrm{O} \text { (Reaction 71) (see Ref. 59). }
$$

NO is rapidly oxidized in irradiated solution to $\mathrm{NO}_{2}$. The $\mathrm{NO}_{2}$ reacts with the water to form equimolar amounts of $\mathrm{NO}_{2}^{-}$and $\mathrm{NO}_{3}^{-}$. The $\mathrm{NO}_{2}^{-}$then associates and repeats the cycle. The result is that any $\mathrm{NO}_{2}^{-}$initially formed is converted to $\mathrm{NO}_{3}^{-}$, and this is the only nitrogen species observed at the end of the experiment.

Linacre and Marsh reported some experiments in which nitrogen gas and water containing kOH were irradiated. 55 In these cases, crly nitrite was observed in solution after irradiation. The explanation they gave was that the nitrogen was fixed first as $\mathrm{NO}_{2}$, which did not associate because of the alkaline $\mathrm{pH}$, and was therefore stable. Conditions in these experiments would have been less oxidizing than in the Bates et al. experiments, because of the absence of oxygen at the start of the experiments. 
The $\mathrm{pH}$ in most of the Bates et al. experiments was also buffered above the $\mathrm{PK}$ of $\mathrm{HNO}_{2}$. However, oxygen was present in addition to the nitrogen. $A$ balance would therefore have been achieved between $\mathrm{NO}_{2}^{-}$and $\mathrm{No}_{3}^{-}$that reflected the oxidation conditions in the solution. Figures 2 and 3 show the nitritenitrate ratios for the two sets of experiments. It can be seen thic the higher dose rate (Fig. 3) generally produced lower ratios of nitrite to nitrate. At the lower dose rate (Fig. 2), the ratios were lowest for the vessels containing water and air only. In the higher rate experiments, those with either tuff or crushed glass present had higher ratios than the others at the end of the irradiation.

These results can probably be explained in part by the balance between production of $\mathrm{H}_{2} \mathrm{O}_{2}$ in the solution by irradiation and its catalytic decomposition by materials such as manganese oxides in the cuff and the glass. The higher dose rate would have produced a higher steadystate $\mathrm{H}_{2} \mathrm{O}_{2}$ concentration. In the water-only vessels, there would have been less catalytic material, so that higher $\mathrm{H}_{2} \mathrm{O}_{2}$ concentrations would have existed. The vessels with either tuff or crushed glass would have had high catalytic surface areas, tending to decompose the $\mathrm{H}_{2} \mathrm{O}_{2} \cdot$ Although $\mathrm{H}_{2} \mathrm{O}_{2}$ does not react directly with $\mathrm{NO}_{2}^{-}$to produce $\mathrm{No}_{3}^{-}$, it can affect the relative concentrations of $e^{-} a_{i}$ and $\mathrm{OH}$ radicals by the reaction:

$$
\mathrm{e}_{\mathrm{aq}}^{-}+\mathrm{P}_{2} \mathrm{O}_{2} \rightarrow \mathrm{OH}+\mathrm{OH}^{-} \quad \mathrm{k}_{4}=1.3 \times 10^{10} \mathrm{M}^{-1} \mathrm{sec}^{-1} \text { (Ref. } 37 \text { ). }
$$

These two free radicals in turn can affect the nitrite-nitrate balance according, the reactions:

$$
\begin{array}{ll}
\left(\mathrm{H}_{2} \mathrm{O}, \mathrm{NO}_{3}^{-}+\mathrm{e}_{\mathrm{aq}}^{-} \rightarrow \mathrm{NO}_{2}+2 \mathrm{OH}^{-}\right. & \mathrm{k}_{72}=1.1 \times 10^{10} \mathrm{M}^{-1} \mathrm{sec}^{-1} \text { (Ref. 37), } \\
\mathrm{NO}_{2}^{-} \mathrm{H} \rightarrow \mathrm{NO}_{2}+\mathrm{OH}^{-} & k_{73}=6.2 \times 10^{9} \mathrm{M}^{-1} \mathrm{sec}^{-1} \text { (Ref. 37), } \\
2 \mathrm{NO}_{2}+\mathrm{H}_{2} \mathrm{O} \rightarrow \mathrm{NO}_{2}^{-}+\mathrm{NO}_{3}^{-}+2 \mathrm{H}^{+} & \text {(Reaction 53). }
\end{array}
$$

In sumnary, the greater catalytic activity of the tuff and/or crushed glass would reduce the $\mathrm{H}_{2} \mathrm{O}_{2}$ concentration. This in turn would raise the ratio of $\mathrm{e}_{\mathrm{aq}}^{-}$to of concentrations. The result of this would be to raise the ratio of $\mathrm{NO}_{2}^{-}$to $\mathrm{NO}_{3}^{-}$concentrations. In addition, $\mathrm{H}_{2} \mathrm{O}_{2}$ would tend to oxidize any trace organics preseltt, thus decreasing the concentrations of these other possible reducing agents. The oil-like films observed in some experiments may be evidence for the presence of organics.

At the end of the lower dose rate experiments, it appears that the nitrite-njtrate ratios were influenced strongly by the types of solid materials present. SRL A glass produced higher ratios than SRL U glass, and 


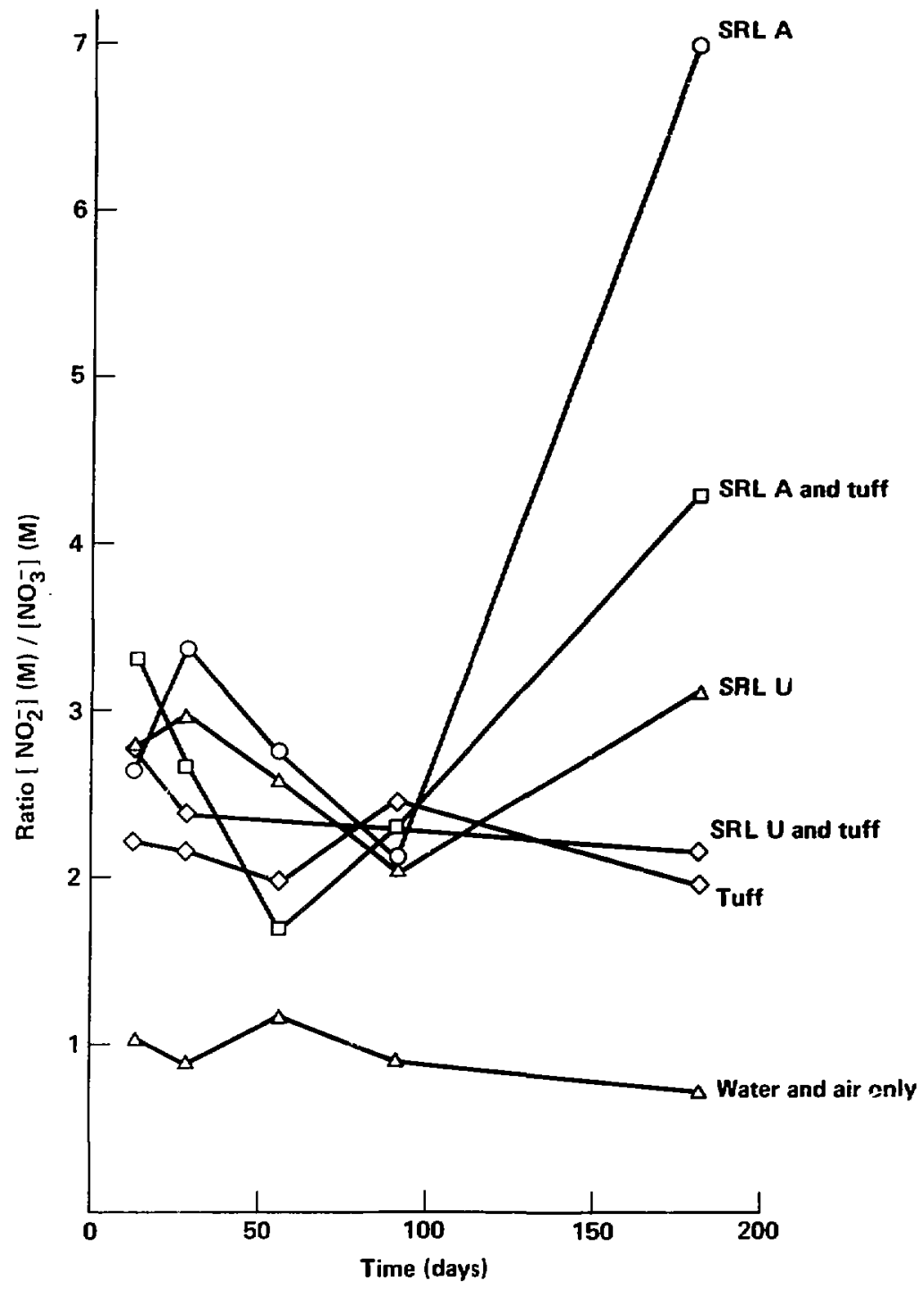

Figure 2. Nitrite-nitrate ratios in $10^{4} \mathrm{rad} / \mathrm{hr}$ experiments. 


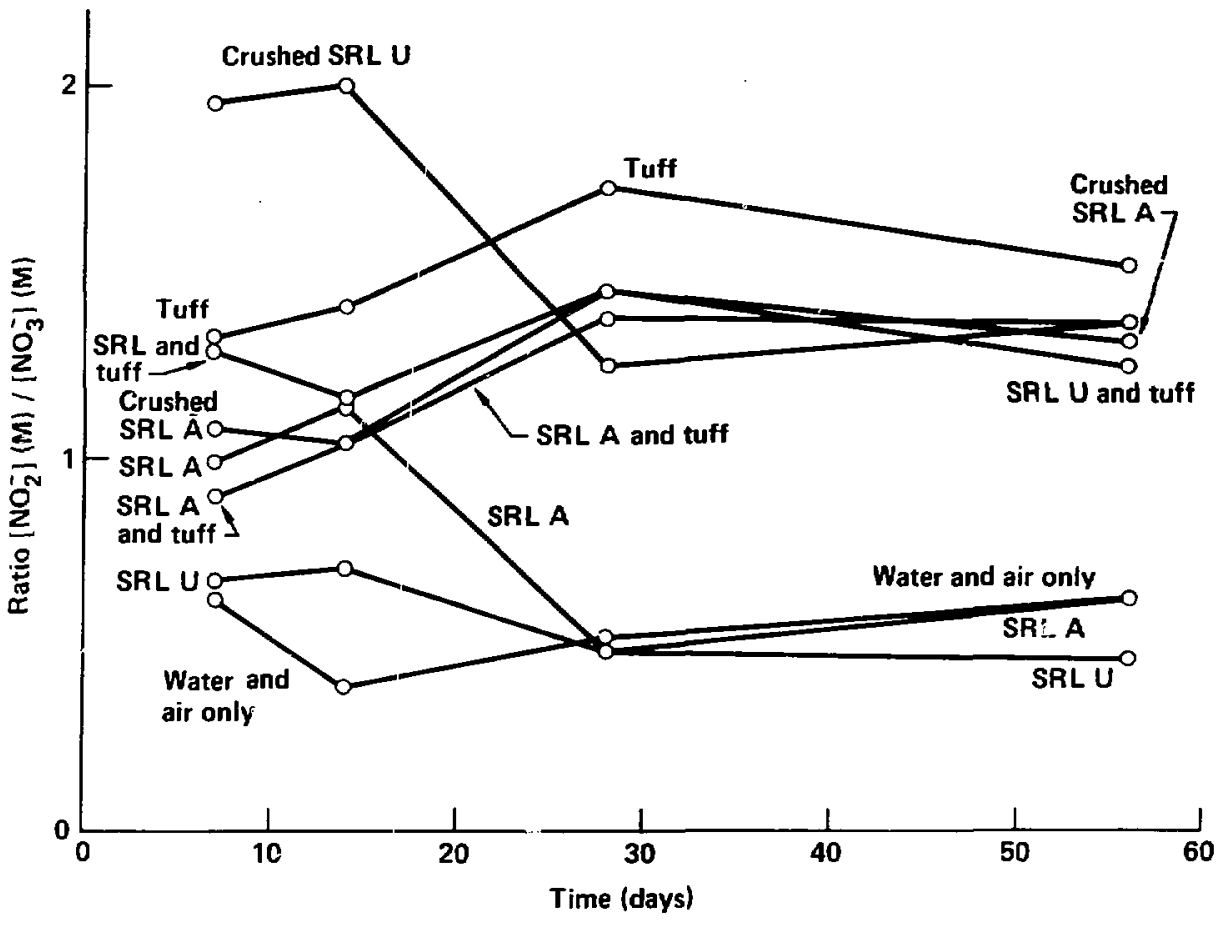

Figure 3. Nitrite-Nitrate ratios in $2 \times 10^{5} \mathrm{rad} / \mathrm{hr}$ experiments. 
the tuff appeared to be lowering the ratios that these glasses would otherwise produce. I do not currently understand the mechanisms behind this behavior. Lower dose rate experiments now in progress should help us to understand this behavior better.

\subsection{LIKELY EFFECTS ON GLASS REACTION}

Gamma irradiation has been found to affect glass dissolution in deionized water in two ways: 1) indirectly through pronotion of an acid pH, which increases the solubility of some elements and nakes $\mathrm{H}^{+}$ions available for attack of the glass structure and for ion exchange and 2) production of free radicals such as $O H$, which can attack the glass directly. It appears that both these effects would be somewhat ameliorated in "equilibrated $\mathrm{J}=13$ " water. The presence of bicarbonate in the solution serves to buffer the $\mathrm{pH}$, so that the solution remains near neutral. In addition, the initial presence of $\mathrm{Cl}^{-}$and $\mathrm{HCO}_{3}^{-}$, and $\mathrm{NO}_{2}^{-}$after some irradiation, serves to lower the on concentration in solution. He would therefore not expect as large an effect on glass dissolution from irradiation with this solution as is observed with deionized or distilled water.

Bates has noted, however, that the solubilities of actinides are highly pH-dependent in the pH range of these experiments, so that even the small changes caused by irradiation may account for the observed differences in the actinide behavior. 22 Nash et al. have discussed the effects of irradiation on actinide behavior during reaction of glass with high purity water. 60 Bates et al. are planning to publish a more complete discussion of the glass behavior they observed in their experiments, at a later date.

\subsection{HIGH GAS-TO-LIQUID VOLUME RATIO EXPERIMENTS}

As noted in section 2, four vessels were irradiated with a smaller initial liquid volume, which produced a larger gas-to-liquid volume ratio. In the first set of experiments, test no. G-113 began with $4.60 \mathrm{ml}$ of deionized water, while test no. G-114 began with $5.16 \mathrm{ml}$ of deionized water. These two vessels also contained a stainless steel waste form holder, but no tuff or glass. They were irradiated for 28 days at $90^{\circ} \mathrm{C}$ and a dose rate of $2 \times 10^{5}$ rad/hour, producing a total dose of 134 Mrad. At the end of the irradiation, 
the vessels were found to contain a flocculant, rust-colored precipitate, and the vessels and waste form holders were visibly corroded. The solutions were very acidic, with the $\mathrm{pH}$ values being 1.82 and 2.58 for G-113 and G-114, respectively. The solutions in both vessels contained significant anounts of elements known to be in stainless steel (Cr, $\mathrm{Cu}, \mathrm{Fe}, \mathrm{Mn}, \mathrm{Ni}$, and $\mathrm{Si}$ ). They also contained 27.2 and $25.6 \mathrm{ppm}$ of nitrate, respectively, and no detectable nitrite. The solutions also contained 589 and $103 \mathrm{ppm}$ of chloride. respectively. The precipitate was found to consist of anorphous material, high in Fe, $\mathrm{Cr}$, and $\mathrm{si}$.

Tests G-265 and G-266 in the second set of experiments had comparable amounts of "equilibrated J-13" (rather than deionized) water. They were irradiated for 182 days at $90^{\circ} \mathrm{C}$ and a dose rate of $1 \times 10^{4} \mathrm{rad} / \mathrm{hr}$, producing a total dose of $44 \mathrm{Mrad}$. They were found to have pr values of 6.94 and 6.88 ,

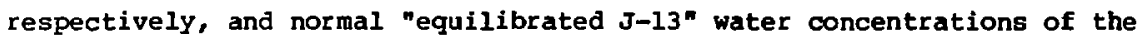
anions $\mathrm{F}^{-}, \mathrm{Cl}^{-}$, and $\mathrm{SO}_{4}^{-2}$. The nitrate concentrations were 4.4 and, $2.1 \mathrm{ppm}$, respectively, and the nitrite concentrations were 10.8 and $7.5 \mathrm{ppm}$, respectively. No corrosion or rust-colored precipitate was evident. A small amount of formate was detected in the solutions.

In test G-113, the predicted concentration of nitrate from equation 2 (Burns et al. ${ }^{7}$ ) is $8.3 \times 10^{-4} \mathrm{M}$, taking uccount of the water expansion and contraction and the space occupied by the holder. The observed concentration was $4.4 \times 10^{-4} \mathrm{M}$, almost a factor of two less. If the calculated amount of nitric acid had formed, the pH would have dropped to 3.1. Thus several anomalous results appeared in tests $G-113$ and $G-114$ : the fixed nitrogen concentration was much lower than calculated; the pH was also much lower; and large concentrations of chloride appeared, the source of which was unknown. Bates performed leach tests on the gasket material at $150^{\circ} \mathrm{C}$ in deionized water for seven days and found no chloride release. 22 He also performed leach tests at $150^{\circ} \mathrm{C}$ for seven days on a stainless steel vessel using deionized water and a $\mathrm{pH} 2 \mathrm{HNO}_{3}$ solution. In these tests he found $14.2 \mathrm{micrograms}$ of $\mathrm{Cl}^{-}$released into the deionized water and 33.7 micrograms released into the $\mathrm{HNO}_{3}$ solution. These results led us to suspect that the $\mathrm{Cl}^{-}$in tests $\mathrm{G}-113$ and $\mathrm{G}-114$ came from the vessels.

A brief study of the chemistry of steel making and consultation with several steel chemists convinced us that chloride should not be present in significant amounts in bulk steel, because of the high vapor pressure of 
chlorides at the melting temperature of steel (see Section 3.14 for results of stainless steel analysis). Fe then looked into the composition of the cutting fluid used to fabricate the vessels and leasned that primsol consists of an emulsion of a chlorinated oil in water. The chlorine composition of the concentrated emulsion sold by Master Chemical company for water dilution by users is about 10.5 wt8. Some of this material may have been buried in the surface during machining and may have survived the cleaning process.

In view of these observations, it appears that the following processes took place in vessels $\mathrm{G}-113$ and G-114. Irradiation produced nitric acid in the solution. The $\mathrm{pH}$ dropped, because there was no buffering. The acid conditions accelerated the corrosion of the stainless steel and formed a positivelY-charged Fe(III)-containing colloid. The corrosion released some form of chlorine that had been buried in the surface of the stainless steel. The chlorine was either initially present in the surface as chloride ions or was reduced to chloride ions by the $H$ and $\mathrm{e}_{\text {aq }}^{-}$radicals, forming $\mathrm{H}^{+}$as well. This led to more rapid corrosion. Some of the anions were attracted and acsorbed by the colloid, which then coagulated and removed them from the solution, forming the rust-colored precipitate. The absence of $\mathrm{N}_{2}^{-}$in the solution resulted from the acid pH, as discussed in Section 3.11 .

The behavior of tests G-265 and G-266 was more similar to the tests with lower ratios of air to water than was the behavior of G-113 and G-114. The predicted increase in fixed nitrogen concentration was $2.7 \times 10^{-4} \mathrm{M}$, compared to the observed values of $1.8 \times 10^{-4} \mathrm{M}$ and $7.5 \times 10^{-5} \mathrm{M}$. The agreement is not very close, but it is noteworthy that these two tests showed the only measurabI= increases in fixed nitrogen in the second set of tests. The differences are probably accounted for by the uncertainties discussed in Section 3.9. The fact that all these values, both calculated and measured, are below the bicarbonate concentration in "equilibrated J-13" water explains why the $\mathrm{pH}$ remained near neutral and no significant corrosion occurred.

\subsection{ANOMALOUS TESTS}

Three tests in the second set of experiments (out of a total of 66) also showed anomalous results: G-208, G-247, and G-248. In all three cases, the irradiation lasted for 91 days. At the end of the tests, the pH values were found to be between 3.6 and 4.8 ; a flocculent, rust-colored precipitate was 
observed; the chloride levels were high (between 73 and $287 \mathrm{ppm}$ ); and other anion concentrations were generally lower than usual. The fixed nitrogen had been lost, rather than added to the solutions.

As mentioned in section 2, other tests in this series produced solutions that were yellow in color, while other parameters were normal. The explanation of these results is probably the sare as for the tests described in Section 3.13. Apparently enough chlorine was accessible to produce the effects even though a buffered solution, rather than deionized water, was present. Analysis of the stainless steel of vessel $\$ 90$, used in test G-247. revealed $0.2 \mathrm{ppm} C l$ by weight in the bulk and a range of 0.5 to 300 ppm at the surface, with an average of $5 \mathrm{ppm}$ on the surface. 22 


\section{CONCLUSIONS}

It appears from this analysis that the observable radiation chemical changes that would have been expected in those vessels of Bates et al. that contained $16 \mathrm{ml}$ of water at the outset of the experiments are the following:

1. Decomposition of a small fraction of the water to hydrogen and oxygen, resulting in an observable pressure increase in the highest dose experiments.

2. Fixation of a small amount of nitrogen from the air as nitrite and nitrate ions in the solution. The increase in total fixed nitrogen should have been measurable in the highest dose experiments.

3. Addition of an equivalent amount of hydrogen ions to the solution, which would be well within the bicarbonate buffering capacity, and which should therefore lower the pH only slightly from what it would be without irradiation.

4. Variation in the nitrite-nitrate ratio, depending on the presence of materials catalytic to the decomposition of hydrogen peroxide. A higher ratio should be observed when catalysts are present.

5. Formation of Fe(III)-containing colloidal material from vessel wall reactions.

It does not appear that measurable amounts of carboxylates (formate or oxalate) should have been formed. The $\mathrm{pH}$ changes, though subtle, could influence actinide solubility so that even the small changes caused by irradiation could produce changes in the amounts of actinides in solution. It appears from an examination of the Bates et al. data that these expectations are largely borne out, except in a few tests that showed anomalously high chloride levels. This chloride most likely came from residues from chlorinated oil cutting fluid buried under the surface of the vessel walls. This emphasizes the need to carefully specify the cutting fluids and cleaning procedures to be used for waste packages. 


\section{APPLICATION TO THE REPOSITORY}

The repository system is expected to differ in a number of ways from the configuration used in the Bates et al. experiments. This is to be expected, since the Bates et al. experiments were designed to represent saturated conditions and to permit control of variables and convenience of operation and analysis, while other engineering considerations apply to the repository case. In applying the experimental results, one must keep these differences in mind:

1. As noted in the Introduction, we expect that most of the nuclear waste glass in the repository would remain dry during the first 300 to 1000 years when significant garma ray fluxes would be present. Under these conditions, aqueous dissolution of the glass would not $\infty c c u r$.

2. The repository would be a physically open system, because of the permeability of the rock. Therefore, gases could escape from the irradiated region, and the total gas pressure would remain at about 0.1 MPa. In addition, any liquid present would be free to migrate through the rock, subject to the constraints of capillarity, permeability, and other factors.

3. The ratio of gas to liquid volume after couling to below the boiling point could be considerably higher in the region near the containers in the repository than in these experiments, particularly if there were only a thin liquid film on the solid surfaces in contact with a relatively large gas space in the annular region around each package.

4. The tuff would have a relatively larger effective surface area in the repository in relation to the areas of metal and glass surfaces than it did in these experiments.

5. The tuff surface in the repository would be essentially in contact with the gas phase (perhaps through a thin liquid film) rather than being submerged under bulk water.

6. The times of interest for the repository would be much longer than those used in the experiments $(100,000$ years versus a few months), but the gamma dose rates would decrease substantially with time (initially with a 30-year half-life) and with distance away from the packages (becoming negligible in tens to hundreds of centimeters). 
7. The temperatures in the repositor I d vary over space and time, rather than being held at a fixed value.

8. The physical dimensions of the waste containers would be much larger than those of the experimental vessels.

9. The repository design may incorporate hole liners made of carbon steel to facilitate retrievability, as required in NRC regulations. This material was not present in the experiments.

These differences and the uncertainties currently surrounding them make the repository a more difficult case to analyze. Nevertheless, the main features seen in the experiments should also be present in the repository:

1. Nitrogen in the gas phase would be fixed in the form of wo at the highest temperatures, then $\mathrm{NO}_{2}$ and $\mathrm{N}_{2} \mathrm{O}_{4}$ at lower temperatures, and finally as $\mathrm{HNO}_{3}$ at temperatures near the boiling point of water. Some of this gas would migrate to moist rock, dissolve, and undergo ion exchange with the feldspars to produce nitrate and nitrite salts in the tuff. Some would react with the metal surfaces to increase their oxidation rates. When the surfaces had cooled so that a liquid film could exist on them, some of the nitrogen oxide gases could dissolve in the film; at that time, the gamma dose rates would be less than a few rad/hr for most of the packages. For those that cooled to below the bolling point while the gamma dose rate was still relatively high, the concentration of fixed nitrogen in the liquid film could increase measurably, particularly if the ratio of gas to liquid volume were large.

2. An equivalent amount of hydroger ions wuld be produced in the liquid film. If this amount did not exceed the buffering capacity of the bicarbonate, the $\mathrm{pH}$ would not whange significantly. If it did, the pH would move in the acid direction, increasing the corrosion rates of the metals.

3. The ratio of nitrite to nitrate would vary, depending on the surface upon which the liquid film rested.

4. Carboxylates (formate and oxalate) should not form in liquid films in contact with tuff or in those which had well-buffered $\mathrm{pH}$ due to dissolved bicarbonate in concentrations in excess of those of radiation-produced hydrogen ions. However, small amounts of carboxylic acids cou?d be expected to form in liquid films that reached low pH as a result of excess 
nitric acid formation. If they formed, they could increase corrosion rates by chelation.

5. The spatial variation of temperature coupled with the large physical size of the packages could give rise to transport and concentration of corrosive species by evaporation and condensation. However, the yolume of the resulting liquid is expected to be small.

6. A carbon steel hole liner, if present, could be expected to scavenge a good share of the corrosive species.

7. Where liquid water containing dissolved species was irradiated, decomposition to hydrogen and oxygen would occur. The rate would depend on the radiation dose rate and would not be constrained by buildup of gas pressure.

As the design parameters of the repository become more firmly fixed, it will be possible to make estimates that are more quantitative of the radiation chemical effects to be expected. In the meantime, the experiments of Bates et al. have provided a number of significant insights. 
REFERENCES

1. R. G. Baxter, Description of Defense Waste Processing Facility Reference Waste Form and Canister, E. I. duPont de Nemours and Co., Savannah River Plant, Aiken, SC, DP-1606 Rev. 1 (1983).

2. L. R. Pederson and G. L. McVay, "Influence of Gamma Irradiation on Leaching of Simulated Nuclear Waste Glass: Temperature and Dose Rate Dependence in Deaerated Water," J. Am. Ceram. Soc. 66, 863 (1983).

3. W. Primak and L. H. Fuchs, "Transportation of Matter and Radioactivity by Ionized Air Corrosion," Physics Today 7, 15 (1954).

4. W. Primak and L. H. Fuchs, "Nitrogen Fixation in a Nuclear Reactor," Nucleonics 13,38 (1955).

5. J. Wright, L. K. Linacre, W. R. Marsh, and T. H. Bates, "Effect of Radiation on Heterogeneous Systems of Air or Nitrogen and water," in Proc. Ist Int'1. Conf. Peaceful Uses Atomic Energy, Geneva, 1955 (United Nations, Geneva, 1956), vol. 7, p. 560 .

6. A. R. Jones, "Radiation-Induced Reactions in the $\mathrm{N}_{2}-\mathrm{O}_{2}-\mathrm{H}_{2} \mathrm{O}$ System," Radiation Research 10, 655 (1959).

7. W. G. Burns, A. E. Hughes, J. A. C. Marples, R. S. Nelson, and A. M. Stoneham, "Effects of Radiation on the Leach Rates of Vitrified Radioactive Waste," J. Nucl. Mater. 107, 245 (1982).

B. W. M. Garrison, D. C. Morrison, J. G. Hamilton, A. A. Benson, and M. Calvin, "Reduction of Carbon Dioxide in Aqueous Solutions by Ionizing Radiation," Science 114, 416 (1951).

9. N. Getoff, G. Scholes, and J. Weiss, "Reduction of Carbon Dioxide in Aqueous Solutions under the Influence of Radiation," Tetrahedron Letters 18, 17 (1960). 
10. N. Getoff, "Synthese organischer stoffe aus Rohlensäure in wässeriger Lösung unter Einwirkung von Co ${ }^{60}$ Gamma-Strahlung," Int'1. J. Appl. Radiation and Isotopes 13, 205 (1962).

11. Aaron Barkatt, Alisa Barkatt, and w. Sousanpour, "Effects of Gama Radiation on the Leaching Rinetics of Various Nuclear Waste-form Materials," Nature 300, 339 (1982).

12. Aaron Barkatt, Alisa Barkatt, and $W$. Sousanpour, "Ganma Radiolysis of Aqueous Media and Its Effects on the Leaching Processes of Nuclear Waste Disposal Materials," Nucl. Technol. 60, 218 (1983).

13. 0. Tamm, "Experimentelle Studien uber die Verwitterung und Tonblldung von Feldspaten," Chem. Erde 7, 420 (1930).

14. C. W. Correns and $w$. von Engelhardt, "Neue Untersuchungen uber die Witterung des Kalifeldspates," Chem. Erde 12, 1 (1938).

15. c. พ. Correns, "Die Chemische Verwitterung der silikate," Naturw. 28, 369 (1940).

16. V. E. Nash and C. E. Marshall, "The Surface Reactions of Siicate Minerals - Part II. Reactions of Feldspar surfaces with Salt solutions," Res. Bull. 614, Univ. of Missouri, Agric. Expt. Station, Columbia, Mo (1956).

17. R. M. Garrels and D. F. Howard, "Reactions of Feldspar and Mica with Water at Low Temperature and Pressure," in Proc. of the Sixth Nat. Conf. on Clays and Clay Minerals, Berkeley, CA, Aug. 19-23, 1957 (Per jamon Press, New York, 1957), p. 68 .

18. J. K. Bates and V. M. Oversby, "The Behavior of Actinide Containing Glasses during Gamma Irradiation in a Saturated Tuff Environment," in proc. of the Materials Research Society Symposium on the Scientific Basis for Nuclear Waste Management VIII, Boston, MA, Nov. 26-29, 1984, C. M. Jantzen et al., Eds. (Materials Research Society, Pittsburgh, PA, 1985), p. 257. 
19. J. K. Bates, D. F. Fischer, and T. J. Gerding, The Reaction of Glass in a Gamma Irradiated Saturated Tuff Environment. Part 1: SRL 165 Glass, Argonne National Laboratory, Argonne, IL, ANL-85-62 (1985).

20. Enviconmental Protection Agency, "Environnental standards for the Management and Disposal of Spent Nuclear Fuel, High-Level and Transuranic Radioactive Fastes; Final Rule," in Code of Federal Regulations, Title 40, Part 191, Federal Register Vol. 50, No. 182, p. 38066 (September 19, 1985).

21. Nuclear Regulatory Comnission, "Disposal of Bigh-Level Radioactive Wastes in Geologic Repositories," in Code of Federal Regulations, Title 10, Part 60 (U.S. Government Printing office, Washington, D.C., 1984).

22. J. K. Bates, Argonne National Laboratory, Argonne, IL, private commurication (1985).

23. R. A. Zielinski, Evaluation of Ash-flow Tuffs as Hosts for Radioactive Waste: Criteria Based on Selective Leaching of Manganese Oxides, U.S. Geological Survey, Denver, Co, Open File Report 83-480 (1983).

24. C. Willis, A. W. Boyd, and M. J. Young, "Radiolysis of Air and NitrogenOxygen Mixtures with Intense Electron Pulses: Determination of a Mechanism by Comparison of Measured and Computed Yields," Can. J. Chem. 48, 1515 (1970).

25. C. Willis and A. W. Boyd, "Excitation in the Radiation Chemistry of Inorganic Gases," Int'1. J. Radiat. Phys. Chem. 8, 71 (1976).

26. R. G. Macdonald and O. A. Miller, "Low Dose-Rate Radiolysis of Nitrogen: Yield of Nitrogen Atoms, $N\left({ }^{4} S\right)$ and $N\left({ }^{2} D,{ }^{2} P\right), "$ Radiat. Phys. Chem. 26, 63 (1985).

27. 0. Tokunaga and N. Suzuki, "Radiation Chemical Reactions in $\mathrm{NO}_{\mathbf{x}}$ and $\mathrm{SO}_{2}$ Removals from Flue Gas," Radiat. Phys. Chem. 24, 1.45 (1984). 
28. F. Busi, M. L'Angelantonio, Q. G. Mulazzani, V. Raffaelli, and o. Tubertini, "Radiation Treatment of Combustion Gases: Formulation and Test of a Reaction Model," Radiat. Phys. Chen. 25, 47 (1985).

29. S. Gordon, K. H. Schmidt, and J. R. Honekamp, "An Analysis of the Hydrogen Bubble Concerns in the Three-Mile Island unit-2 Reactor Vesse1," Raáiat. Phys. Chem. 21, 247 (1983).

30. W. G. Burns and P. B. Moore, "Water Radiolysis and Its Effect upon In-Rejctor Zircaloy Corrosion," Rad, Effects 30, 233 (1976).

31. A. W. Boyd, M. B. Carver, and R. S. Dixon, "Computed and Experimental Product Concentrations in the Radiolysis of Water," Radiat. Phys. Chem. 15, $1 \%$ (1980).

32. H. Christensen and E. Bjergbakke, "Radiolysis of Ground water from Spent Fuel," Svensk Karnbransleforsorjning AB/Avdelning KBS, Stockholm, Sweden, SKBF KBS Report No. 82-18 (1982).

33. S. A. Simonson and W. L. Kuhn, "Predicting Amounts of Radiolytically Produced Species in Brine Solutions," in Proc. of the Mater. Research soc. Symp. on the Sci. Basis for Nucl. Waste Management, Boston, Mass., Nov. 14-17, 1983, G. L. MaVay, Ed. (Elsevier, New York, 1984), p. 781.

34. S. L. Nicolosi, "A Generalized Model for the Analysis of Groundwater Radiolysis," in Proc. of the Mater. Res. Soc. Symp. on the Sci. Basis for Nucl. Waste Management VIII, C. M. Jantzen et al., Eds. (Materials Research Society, Pittsburgh, PA, 1985), p. 631.

35. T. Eriksen and A. Jacobsson, "Radiation Effects on the Chemical Environment in a Radioactive Waste Repository," Svensk Karnbransleforsorjning AB/Avdelning KBS, Stockholm, Sweden, SKBF KBS Report No. 83-27 (1983). 
36. W. G. Burns, W. R. Marsh, and W. S. Halters, "The Gama IrradiationEnhanced Corrosion of Stainless and Mild Steels by Nater in the Presence of Air, Argon, and Hydrogen," Radiat. Phys. Chem. 21, 259 (1983).

37. J. W. T. Spinks and R. J. Foods, An Introductior to Radiation Chenistry (Wiley, New York, 1976), 2nd ed.

38. C. J. Hochanadel and J. A. Ghormley, "Effect of Tenperature on the Decomposition of Water by Gama Rays," Radiat. Res. 16, 653 (1962).

39. G. G. Jayson, B. J. Parsons, and A. J. Swallow, "Some Simple, Highly Reactive, Inorganic Chlorine Derivatives in Aqueous Solution," $\mathbf{J}$. Chem. Soc. Faraday Trans. I 69, 1.597 (1973).

40. D. Behar, G. Czapski, and I. Duchovny, "Carbonate Radical in Flash Photolysis and pulse Radiolysis of Aqueous Carbonate Solutions," J. Phys. Chem. 74, 2206 (1970).

41. G. E. Adams, J. W. Boag, and B. D. Michael, "Transient Species Produced in Irradiated Water and Aqueous Solutions Containing Oxygen," Proc. Roy. Soc. London, Ser. A 289, 321 (1965).

42. E. Hayon and J. J. McGarvey, "Flash Photolysis in the vacuum Ultraviolet Region of $\mathrm{SO}_{4}^{2-}, \mathrm{CO}_{3}^{2-}$, and $\mathrm{OH}^{-}$Ions in Aqueous Solutions," J. Phys. Chem. 71, 1472 (2967).

43. T. E. Eriksen, J. Lind, and G. Merenyi, "On the Acid-Base Equilibrium of the Carbonate Radical," Radiat. Phys. Chem. 26, 197 (1985).

44. K. V. Baczko, Ed., Gmelin Handbuch der Anorganischen Chemie, SystemNummer 14, Part C, Number 3, "Kohlenstoff" (Verlag Chemie-GMBR, Weinheim/Bergstrasse, Germany, 1973), p. 123.

45. F. A. Cotton and G. Wilkinson, Advanced Inorganic Chemistry (Wiley, wew York, 1980). 
46. W. J. Gray and S. A. Simonson, "Ganma and Alpha Radiolysis of Salt Brines," in Proc. of the Materials Research Society Sydp. on the Sci. Basis for Nucl. Haste Management VIII, Boston, Mass., Nov. 26-29, 1984. C. M. Jantzen et al., Eds. (Materials Research Society, Pittsburgh, PA, $1985)$, p. 623 .

47. A. Pojtik, G. Czapski, and A. Henglein, "Pulse Radiolytic Investigation of the Carboxyl Radical in Aqueous Solution," J. Phys. Chem. 74, 3204 (1970).

48. J. P. Reene; Y. Raef, and A. J. Swallow, "Pulse Radiolysis studies of Carboxyl and Related Radicals," in Pulse Radiolysis, Proc. of the Int'l. Symp., Manchester, England, April, 1965 (Academic, New York, 1965), p. 99.

49. I. G. Draganic and 0. Gal, "Radiation Chemistry of Oxalic Acid and Oxalates," Rad. Res. Rev. 3, 167 (1971).

50. H. Stephen and T. Stephen, Solubilities of Inorganic and Organic Compounds, Vol. 1, Binary Systeins, Part 1 (Macmillan, New York, 1963), p. 251 .

51. T. Hasselstrom and M. C. Henry, "New Synthesis of Oxalic Acid," Science 123, 1038 (1956).

52. M. C. Juhas, R. D. McCricht, and R. E. Garrison, Behavior of stressed and Unstressed 304L Specimens in Tuff Repository Environmental Conditions, Lawrence Livermore National Laboratory, UCRL-91804 (1985) (presented at Corrosion '85, National Association of Corrosion Engineers Annual Meeting, Boston, MA, Marc'il 25-29, 1985).

53. R. S. Glass, R. A. Van Konynenburg, and G. E. Overturf, "Corrosion Processes of Austenitic stainless steels and Copper-Based Materials in Gamma-Irradiated Aqueous Environments," Lawrence Livermore National Laboratory, UCRL-92941 (1986) (presented at Corrosion '86, National Association of Corrosion Engineers Annual Meeting, Houston, Texas, March $17-21,1986)$. 
54. W. C. Schumb, C. N. Satterfield, and R. L. Wentworth, Bydrogen Peroxide (Reinhold, New York, 1955).

55. J. K. Linacre and W. R. Marsh, "The Radiation Chemistry of Heterogeneous and Homogeneous Nitrogen and Nater systens," Chemistry Division, ARRE Harwell, England (.1981), AERE-R10027.

56. J. A. Roth and D. E. Sullivan, "Solubility of Ozone in Water," Ind. Bng. Chem. Fundam. 20, 137 (1981).

57. M. Pourbaix, Atlas of Electrochemical Equilibria in Aqueous Solutions (Pergamon, New York, 1966).

58. R. A. Van Konynenburg, Lawrence Livermore National Laboratory, unpublished data discussed in internal memorandum entitled "Water Chemistry Results from Corrosion Experiment No. 11 (General Corrosion of Stainless Steels in Hot, Unirradiated J-13 water)," October 22, 1985.

59. W. L. Jolly, The Inorganic Chemistry of Nitrogen (W. A. Benjamin, New York, 1964).

60. K. L. Nash, S. Fried, A. M. Friedman, N. Susak, P. Rickert, and J. C. Sullivan, "Radiation Effects in Solution and on the Solid/Liquid Interface," Nucl. Technol. 60, 257 (1983).

61. R. C. Weast and M. J. Astle, Eds., CRC Handbook of Chemistry and Physics (CRC Press, Boca Raton, FL, 1982), 63rd ed.

62. J. H. Keenan, F. G. Keyes, P. G. Hill, and J. G. Moore, Steam Tables (Wiley, New York, 1978).

63. J. A. Dean, Ed., Lange's Handbook of Chemijtry (McGraw-Hill, New York, 1979), 12 th ed.

64. A. M. Amorosi and J. R. McDermet, "The Calculation of the Distribution of Carbon Dioxide Between Water and Steam," ASTM Proc. 39, 1204 (1939). 
65. P. Cohen, Water Coolant Technology of Power Reactors (American Nuclear Society, La Grange Park, IL, 1969).

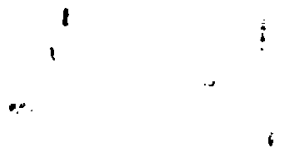

